\title{
Trends in Extreme Climate Events over Three Agroecological Zones of Southern Ethiopia
}

\author{
Befikadu Esayas $\mathbb{D}^{1},{ }^{1}$ Belay Simane, ${ }^{1}$ Ermias Teferi, ${ }^{1}$ Victor Ongoma ${ }^{D},{ }^{2}$ \\ and Nigussie Tefera ${ }^{3}$ \\ ${ }^{1}$ Center for Environment and Development Studies, Addis Ababa University, P.O. Box 1176, Addis Ababa, Ethiopia \\ ${ }^{2}$ Department of Meteorology, South Eastern Kenya University, P.O. Box 170-90200, Kitui, Kenya \\ ${ }^{3}$ The United Nations, World Food Programme (WFP), Addis Ababa, Ethiopia
}

Correspondence should be addressed to Befikadu Esayas; befikadu.esayas@aau.edu.et

Received 6 June 2018; Revised 9 August 2018; Accepted 12 September 2018; Published 16 October 2018

Academic Editor: Marina Baldi

Copyright (c) 2018 Befikadu Esayas et al. This is an open access article distributed under the Creative Commons Attribution License, which permits unrestricted use, distribution, and reproduction in any medium, provided the original work is properly cited.

\begin{abstract}
The study aims to assess trends in extremes of surface temperature and precipitation through the application of the World Meteorological Organization's (WMO) Expert Team on Climate Change Detection and Indices (ETCCDI) on datasets representing three agroecological zones in Southern Ethiopia. The indices are applied to daily temperature and precipitation data. Nonparametric Sen's slope estimator and Mann-Kendall's trend tests are used to detect the magnitude and statistical significance of changes in extreme climate, respectively. All agroecological zones (AEZs) have experienced both positive and negative trends of change in temperature extremes. Over three decades, warmest days, warmest nights, and coldest nights have shown significantly increasing trends except in the midland AEZ where warmest days decreased by $0.017^{\circ} \mathrm{C} /$ year $(p<0.05)$. Temperature extreme's magnitude of change is higher in the highland AEZ and lower in the midland AEZ. The trend in the daily temperature range shows statistically significant decrease across AEZs $(p<0.05)$. A decreasing trend in the cold spell duration indicator was observed in all AEZs, and the magnitude of change is 0.667 days/year in lowland $(p<0.001), 2.259$ days/year in midland, and 1 day/year in highland $(p<0.05)$. On the contrary, the number of very wet days revealed a positive trend both in the midland and highland AEZs $(p<0.05)$. Overall, it is observed that warm extremes are increasing while cold extremes are decreasing, suggesting considerable changes in the AEZs.
\end{abstract}

\section{Introduction}

The Intergovernmental Panel on Climate Change (IPCC) report shows that climate change is evident by high frequency in climate extreme events including flooding, drought, sea level rise, and heat waves [1]. Various studies have shown changes in the occurrence and severity of climate extreme events, along with the variability of weather patterns, causing substantial impacts on human and natural systems [2-4]. Climate change impacts, however, are differently experienced in different parts of the world owing to various geographic settings and socioeconomic factors $[3,5]$. With a projected 3 to $4^{\circ} \mathrm{C}$ temperature increase, climate change impact in the future will result in more hostile environments, associated with increases in the frequency and severity of floods and droughts $[3,6]$. Furthermore, the IPCC reports illustrate that the intensity and occurrence of extreme events are expected to increase in different parts of Africa $[2,3]$. Climate models have shown that climate impacts will be severe in many areas of Africa, including East Africa $[7,8]$, primarily associated with changes in atmospheric forcing due to anthropogenic causes [9].

Due to the adverse effects of climate variability and change, Ethiopia is considered to be one of the most vulnerable countries $[10,11]$. The country largely suffers from hazards linked to high rainfall variability $[12,13]$ and climate extreme events [14]. It has experienced droughts and floods from the 1980s onwards [10], and since 1990, the country has recorded 47 major floods that killed about 2,000 people and affected close to 2.2 million people [15]. Ethiopia also 
experienced 12 major droughts between 1900 and 2010 that claimed the lives of over 400,000 people, and the number of those affected was over 54 million [15]. Very recently, the 2015 El Niño-induced drought has caused food insecurity among 10.2 million people, one of the highest on the record [16]. Moreover, it is projected that Ethiopia will face serious and damaging impacts resulting from changing climate patterns in the future [17].

Owing to the high probability of changes in climate extremes and the negative economic, social, and environmental impacts $[2,18,19]$, due consideration has been given to the analysis of climate extreme events in recent years $[20,21]$. This is because climate extremes respond more sensitively to climate change than changes in the average climates [21, 22]. Furthermore, extreme events affect the ecosystems much more than changes in the mean climate $[23,24]$. Following the IPCC [6] definition, in this study, an "extreme event" is used to illustrate the occurrence of a value of a weather or climate variable above or below a threshold value, generally occurring at the tails of the probability density function (PDF) of the range of observed values of the variable within a defined climate reference period.

Temperature and rainfall are the two most significant and sensitive climatic elements in tropical regions. Data regarding extreme climates and their characteristics are essential to identify, plan, implement, monitor, and evaluate different socioeconomic activities in developing economies such as Ethiopia. In Ethiopia, responding to the negative impacts of extreme climates on the smallholder lives and livelihoods requires detailed studies that document the extent and trends of changes in the extreme climate events. Thus, this study considers the local level analysis of extreme climate events as a case study, which may help to react timely to the associated shocks.

Some empirical studies have attempted to analyze the extreme climatic events in Ethiopia but found mixed results owing to contextual differences. Despite varied results in the magnitude of change observed, a growing body of literature now points to significant trends in precipitation and temperature extremes. For example, a negative trend was observed in seasonal extreme rainfall [25], while mixed trends of changes were reported in rainfall extremes [26-29]. Several empirical studies suggest positive trends in air temperature and negative trends in rainfall [30-33]. A study by Viste et al. [34] reported that even through the degree of drying varies spatially, all the studied areas experienced drought at annual scales in Ethiopia. Zeleke et al. [35] documented that south and southwestern regions of Ethiopia have experienced drying, while the central mountainous, north, and northwestern regions had no observed long-term trends. Recently, Worku et al. [36] reported a warming trend in extreme temperature indices while an increase in rainfall extreme events in Jemma Subbasin, Upper Blue Nile Basin. However, Kebede et al. [37] reported neither a clear monotonic trend in dry spells nor a significant variation in the rainfall duration, onset, and cessation. In Ethiopia, different studies reported that there has been inconsistency in patterns in the precipitation extremes [25-28, 31, 33, 36, 38]. Regardless of the inconsistency in the rainfall extremes in Ethiopia, recent evidence shows that the frequency of the occurrences of extreme events and their variability has increased over the last 20 years [3, 36, 39, 40]. In the context of the study area, a recent study by Degefu and Bewket [38] revealed that the geographic distribution on the occurrence and magnitude of observed drought events was complex.

Although the abovementioned studies have documented trends in climate extremes at national, regional, and local levels, the studies have been reporting different patterns in the climate extremes mostly focusing on the national level analysis with a lot of emphasis on drought. A few studies have examined variations in rainfall extremes using selected indices at national and subnational levels, which may not fully explain the situation at the local level. Though others have assessed trends of climate extremes, most of the studies are spatially confined to the northern part of Ethiopia with the exception of the recent study by Degefu and Bewket [38] that analyzed trends of climate extremes in Omo-Ghibe River basin. Therefore, the existing information on climate extremes is limited in scope, is fragmented in coverage, and does not provide complete perspectives on the complex topography, relief, and agroecological settings in Ethiopia [26, 41].

Unlike earlier studies, this study focuses on aggregation and disaggregation by agroecological zones (AEZs) because of the increasing importance of agroecological-based analysis in the face of changing climate extremes. Case studies based on such a perspective (e.g., climate resilience to farm productivity) in the context of climate variability and change are very important [42]. This reveals on the importance of agroecological-based approach as one of the scientific disciplines, sustainable farming approach, and social movement [42]. Moreover, with the changing climate extremes and their adverse effects on peoples' livelihoods, some attempts have been made to promote "agroecology as the sustainable alternative to climate change crisis" [43]. In the Ethiopian context, existing evidence suggest that different agroclimatic zones are found. Traditionally, the agroecologies have been classified into five categories based on altitude, rainfall, and temperature (Table 1) [44, 45].

More importantly, the design and development of local level climate adaptation options and enhancing early warning systems require us to understand the characteristics and trends in climate extreme events at different geographical scales. This study thus contributes to the rapidly growing climate extreme literature by providing first-hand evidence both on the temperature- and precipitation-based indices at AEZs in Southern Ethiopia. It also gives new insights into the application of gridded data at a microlevel where finding complete station data is a serious challenge. The study, by employing climate extreme indices-as one way to investigate climate change and variability in the study area, can serve as a reference for similar studies in the future.

In summary, this study intends to better the understanding of changes and trends in extreme climate events and their frequency, and duration, and variability over three AEZs of Wolaita Zone, Southern Ethiopia. It aims at (a) analyzing the magnitude and frequency of occurrence of extreme temperature events and (b) analyzing the magnitude and frequency of occurrence of extreme precipitation events in AEZs. The rest of 
TABLE 1: Traditional agroecological zones and their physical features.

\begin{tabular}{lcccc}
\hline AEZs & Altitude (meters) & Rainfall (mm/year) & Growing period length (days) & Mean annual temperature $\left({ }^{\circ} \mathrm{C}\right)$ \\
\hline Upper highland (Wurch) & Above 3200 & $900-2200$ & $211-365$ & $<11.5$ \\
Highland (Dega) & $2,300-3,200$ & $900-1,200$ & $121-210$ & $17.5 / 16-11.5$ \\
Midland (Weyna Dega) & $1,500-2,300$ & $800-1,200$ & $91-120$ & $17.5 / 16-11.5$ \\
Lowlands (Kola) & $500-1,500$ & $200-800$ & $46-90$ & $27.5-20$ \\
Desert (Berha) & Below 500 & Below 200 & $0-45$ & $>27.5$ \\
\hline
\end{tabular}

Adapted from MoA [45].

the paper is organized into three sections: Section 2 provides a brief description of the data, methodology, and area of study; Section 3 presents and discusses the study findings; and the conclusions of the study are given in Section 4.

\section{Study Area, Data, and Methodology}

2.1. Study Area. Wolaita Zone is located in Southern Nation Nationalities and People (SNNP) of Ethiopia. It lies between $6.4^{\circ}-7.1^{\circ} \mathrm{N}$ and $37.4^{\circ}-38.2^{\circ} \mathrm{E}$ (Figure 1). It is grouped into three traditional agroecological zones: $56 \%$ of the area is midland (Weyna Dega); 35 \% of the area is lowland (Kola); and the rest $9 \%$ of the area is covered by highland (Dega) (Table 1) [46]. The relief of the area is generally a highland that covers most parts of the midland while the peripheries are lowland areas (Figure 1). The altitude ranges from 501 meters in the lowlands at BilateTena to 3000 meters above the sea level in the highlands at the Damota mountain area. The amount, period, and frequency of rainfall vary considerably from one AEZ to the other. The mean annual rainfall ranges from $800 \mathrm{~mm}$ in BilateTena to the highest $1,200 \mathrm{~mm}$ in Wolaita Sodo. Rainfall is erratic by nature and variable, occurring in two dissimilar seasons. The pattern of rainfall distribution is bimodal. The main rainy season (Kirmet) starts in mid-June and extends to the end of September. The second one is the Belg season that spans from the end of February to March and/or early April [46]. The mean annual minimum temperature ranged from 15.1 to $25.1^{\circ} \mathrm{C}$ in $2015 / 2016$. However, temperatures are usually high with little variations among seasons. In the same year, the mean annual maximum temperature was reported between $17.1^{\circ} \mathrm{C}$ and $29.7^{\circ} \mathrm{C}$. Following Hurni [47], this study adopted the traditional AEZ grouping approach, where three meteorological stations' daily minimum and maximum temperature and daily precipitation data were extracted using the latitude and longitude to represent highland, midland, and lowland AEZs, respectively (Figure 1).

2.2. Data. The study is based on gridded dataset ( $4 \mathrm{~km}$ by $4 \mathrm{~km}$ spatial resolution) of daily maximum and minimum temperatures and daily total rainfall from 1983 to 2014 . The gridded dataset combines two datasets: the first is station data (rainfall and temperature) from the national network managed by the Ethiopian National Meteorological Services Agency (NMA) and the second dataset is satellite rainfall and temperature estimations from European Organization for the Exploitation of Meteorological Satellites (EUMETSAT) and the US National Aeronautics and Space Administration (NASA).
In other words, the gridded dataset integrated qualitycontrolled station data from the national observation network with locally calibrated satellite-derived data that were used to fill spatial and temporal gaps in the Ethiopian national observations. Data reconstruction was undertaken by the NMA in partnership with International Research Institute for Climate and Society at Columbia University, USA, whereas data calibration and validation were carried out by Reading University, UK.

As mentioned by Mengistu et al. [48] in the Upper Nile Basin, Ethiopia, station-based data in the Wolaita Zone had also many missing values and measurement errors, was poor in quality, and lacks continuous data both for temperature and precipitation. Due to these reasons, the preference was given to the use of the gridded dataset, which had better data quality and daily minimum and maximum temperature, and daily total precipitation data were available between 1983 and 2014 for the studied AEZs as opposed to using the available station-based dataset. The data used for this study can be found at Ethiopian National Meteorological Services Agency (http://www.ethiomet.gov.et/) for the climatic stations located over three agroecological zones.

On the contrary, this study considered three existing stations, which are located over the AEZs using the gridded dataset for the purpose of comparison by AEZ, which in turn is assumed to represent each AEZ with the available climate data over the study period (1983-2014) (Figure 1). The stations include Bilate (lowland), Wolaita (midland), and Boditi School (highland) (Table 2). The stations were selected purposively as they have long years (over 30 years) of observed temperature and rainfall data. The analysis period, 1983-2014, was chosen due to data availability within the selected periods and to explore the recent change in extreme temperature and rainfall across the study AEZs. Data quality control was carried out using ClimPACT2 Software in R [49]. Data quality was tested in order to label potentially wrong values and to remove them from the analysis. Unrealistic values, such as daily maximum temperature less than or equal to daily minimum temperature, were identified and set to missing values. The reference period of 1983-2000 was chosen out of the full-time range (1983-2014) mainly for the calculation of the percentile-based indices.

2.3. Methodology. In an effort to investigate the existence of trends in time series of both temperature and rainfall indices obtained from daily data, we used the nonparametric Mann-Kendall (MK) test statistic $[50,51]$ and Sen's estimator test [52] at the 5\% significant level. Detailed description on Mann-Kendall and Sen's slope estimation can be found from the related studies [53-56], as described in 


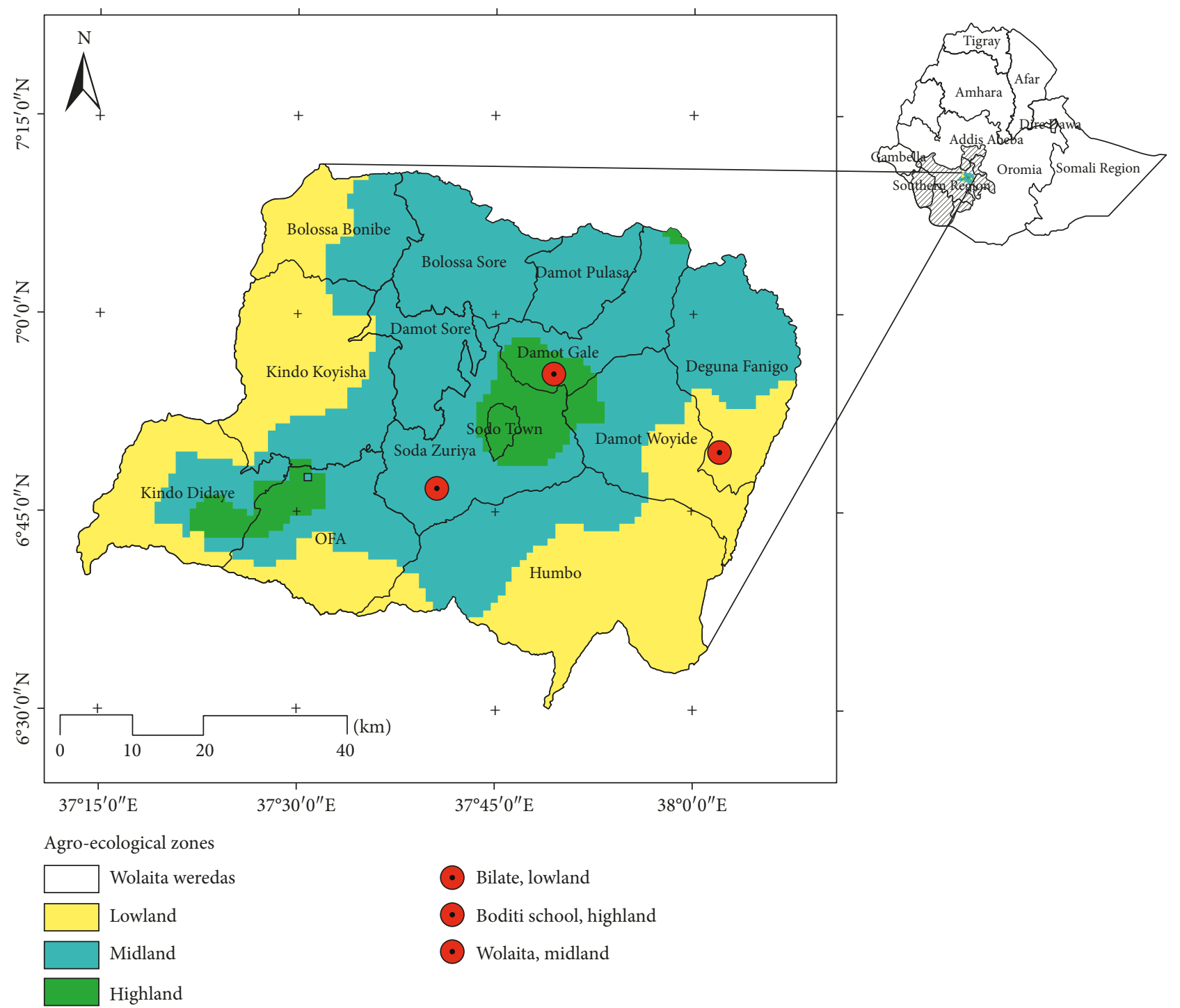

FigURE 1: Location of agroecological zones.

TABLE 2: Selected meteorological station in Wolaita Zone.

\begin{tabular}{|c|c|c|c|c|c|c|}
\hline No. & Station name & Longitude & Latitude & Altitude (m) & AEZs & Duration \\
\hline 1 & Boditi School & 37.96 & 6.95 & 2043 & Highland & $1983-2014$ \\
\hline 2 & Wolaita & 37.58 & 6.81 & 1854 & Midland & 1983-2014 \\
\hline 3 & Bilate & 38.08 & 6.81 & 1361 & Lowland & 1981-2014 \\
\hline
\end{tabular}

Supplementary Materials (available here). The stations are not only representative of elevation but also other criteria as suggested by MoA [45], which grouped AEZs into five categories based on altitude (meters), rainfall (mm/year), growing period length (days), and mean annual temperature $\left({ }^{\circ} \mathrm{C}\right)$ (Table 1$)$.

\section{Results and Discussion}

\subsection{Trends in Temperature Extremes}

3.1.1. Warm Days (TX90p) and Warm Nights (TN90p).
Trends for the temperature indices for the three AEZs are shown in Table 3. From the percentile-based temperature indices, significantly increasing trend in the frequency of warm days (TX90p) was observed both in the lowland (Figure 2(a)) and highland AEZs (Figure 2(e)) $(p<0.05$ and $p<0.001)$, respectively. The TX90p shows an insignificant decreasing trend in the midland AEZ (Figure 2(c)). Similar to the frequency of TX90p reported in lowland and in highland AEZs, the occurrence of warm nights (TN90p) has shown very significant increasing trends $(p<0.001)$ (Figure 2(b)) for the lowland AEZ and (Figure 2(f)) for highland AEZ, respectively. The increasing trend observed in the two 
TABLE 3: Trends in temperature extreme indices per year by AEZ.

\begin{tabular}{|c|c|c|c|c|c|c|c|}
\hline \multirow{2}{*}{ Index } & \multirow{2}{*}{ Units } & \multicolumn{2}{|c|}{ Lowland AEZ } & \multicolumn{2}{|c|}{ Midland AEZ } & \multicolumn{2}{|c|}{ Highland AEZ } \\
\hline & & MK test $(Z$-test $)$ & Sen's slope & MK test $(Z$-test $)$ & Sen's slope & MK test (Z-test) & Sen's slope \\
\hline TX90p & $\%$ & $0.315^{*}$ & $0.326^{*}$ & $-0.177^{\mathrm{ns}}$ & $-1.501^{\mathrm{ns}}$ & $0.480^{* * *}$ & $0.565^{* * *}$ \\
\hline TX10p & $\%$ & $-0.234^{\mathrm{ns}}$ & $-0.158^{\mathrm{ns}}$ & $-0.089^{\mathrm{ns}}$ & $-0.05^{\mathrm{ns}}$ & $-0.363^{*}$ & $-0.284^{*}$ \\
\hline TN90p & $\%$ & $0.552^{* * *}$ & $0.547^{* * *}$ & $0.198^{\text {ns }}$ & $0.234^{\mathrm{ns}}$ & $0.572^{* * *}$ & $0.61^{* * *}$ \\
\hline TN10p & $\%$ & $-0.659^{* * *}$ & $-0.349^{* * *}$ & $-0.612^{* * *}$ & $-0.605^{* * *}$ & $-0.686^{* * *}$ & $-0.264^{* * *}$ \\
\hline TXx & ${ }^{\circ} \mathrm{C}$ & $0.258^{*}$ & $0.025^{*}$ & $-0.252^{*}$ & $-0.017^{*}$ & $0.523^{* * *}$ & $0.042^{* * *}$ \\
\hline TXn & ${ }^{\circ} \mathrm{C}$ & $0.137^{\mathrm{ns}}$ & $0.01^{\mathrm{ns}}$ & $0.141^{\mathrm{ns}}$ & $0.012^{\mathrm{ns}}$ & $0.290^{*}$ & $0.024^{*}$ \\
\hline $\mathrm{TNx}$ & ${ }^{\circ} \mathrm{C}$ & $0.462^{* * *}$ & $0.055^{* * *}$ & $0.407^{* * *}$ & $0.037^{* * *}$ & $0.597^{* * *}$ & $0.063^{* * *}$ \\
\hline $\mathrm{TNn}$ & ${ }^{\circ} \mathrm{C}$ & $0.653^{* * *}$ & $0.078^{* * *}$ & $0.581^{* * *}$ & $0.075^{* * *}$ & $0.690^{* * *}$ & $0.084^{* * *}$ \\
\hline WSDI & Days & $0.156^{\mathrm{ns}}$ & $2.00^{\mathrm{ns}}$ & $-0.322^{\mathrm{ns}}$ & $-1.000^{\mathrm{ns}}$ & $0.270^{\mathrm{ns}}$ & $2.667^{\mathrm{ns}}$ \\
\hline CSDI & Days & $-0.652^{* * *}$ & $-0.667^{* * *}$ & $-0.566^{*}$ & $-2.259^{*}$ & $-0.591^{*}$ & $-1.00^{*}$ \\
\hline DTR & ${ }^{\circ} \mathrm{C}$ & $-0.367^{*}$ & $-0.052^{*}$ & $-0.423^{* * *}$ & $-0.053^{* * *}$ & $-0.282^{*}$ & $-0.043^{*}$ \\
\hline
\end{tabular}

ns: nonsignificant, $p>0.05 ;{ }^{*} p \leq 0.05 ;{ }^{* *} p \leq 0.01 ;{ }^{* * *} p \leq 0.001$.

AEZs is in agreement with results from the three ecoenvironments in Ethiopia [31] and Worku et al. [36]. On the contrary, the midland AEZ experienced insignificant increasing trend in the TN90p (Figure 2(c)). The annual number of TN90p and TX90p shows significant warming anomalies for the period 1983-2014 both in the lowland and highland AEZs. The TX90p reaches its peak in 2009 for the lowland AEZ (Figure 2(a)) and in 2012 for the highland AEZ (Figure 2(e)). On the contrary, TN90p peaked in 2010 in the lowland AEZ (Figure 2(b)) and in 2014 for the highland AEZ (Figure 2(f)). In general, from 2008 onwards, warming anomalies are consistently increasing in all AEZs.

3.1.2. Cool Days (TX10p) and Cool Nights (TN10p). Insignificant decreasing trend in the frequency of cool days (TX10p) was observed in the lowland AEZ (Figure 3(a)) and midland AEZ (Figure 3(c), respectively. However, TX10p shows a decreasing trend in the highland AEZ $(p<0.05)$ (Figure 3(e)). Concerning the frequency of cool nights (TN10p), a very significant decreasing trend was observed in all AEZs $(p<0.001)$, and the result is in line with the recent work by Worku et al. [36]. The negative anomalies are consistently declining since the late 1980s both in the lowland (Figure 3(b)) and highland AEZs (Figure 3(f)), respectively. On the contrary, except for the years 1997 to 1999, the midland AEZ also experienced negative anomalies for the TN10p between late 1980s and 2014 (Figure 3(d)). All the AEZs have experienced a very significant decreasing trend in the TN10p over the period between 1983 and 2014. The significantly increasing trends in the occurrences of TX90p and TN90p while decreasing trends in TX10p and TN10p are in agreement with results from other studies that have analyzed these trends in different parts of the world [57-60].

In summary, two of the AEZs have experienced significant increases in TX90p and TN90p over the period between 1983 and 2014 while no significant trends were observed for all indices in the midland AEZ except for TN10p. The figures are indicative of the increasing trends in the warm extremes and decreasing trends in the cold extremes. These figures clearly show significant warming. In view of this, Worku et al. [36] reported similar pattern of trends both in cold and warm extremes in Upper Blue Nile Basin. Moreover, empirical studies in East Africa, including Ethiopia, suggest that the frequencies of warm days and nights compared to the initial time showed a large increase vis-à-vis the number of cold nights per year beyond the $90^{\text {th }}$ percentile threshold [61].

3.1.3. Warmest Day (TXx) and Coldest Day (TXn). The trend in the warmest day $(\mathrm{TXx})$ is statistically significant with the magnitude of change being $0.025^{\circ} \mathrm{C} /$ year $(p<0.05)$ for the lowland AEZ, while the magnitude of change in the highland AEZ was observed to be $0.042^{\circ} \mathrm{C} /$ year $(p<0.001)$. The TXx in the midland AEZ showed a statistically significant decreasing trend $\left(0.017^{\circ} \mathrm{C} /\right.$ year $)(p<0.05)$ (Table 3$)$. The TXx reached its peak in 2009 for the lowland AEZ (Figure 4(a)), in 2012 for the midland AEZ (Figure 4(c)), and in 2011 for the highland AEZ (Figure 4(e)). The temperature of the coldest day (TXn) is significantly increasing in the highland AEZ with the magnitude of change being $0.024^{\circ} \mathrm{C} /$ year $(p<0.05)$, while this index is insignificant in the lowland and midland AEZs (Figures 4(b)) and 4(d)). A study by Mekasha et al. [31] reported a similar trend in Ethiopia where TXn values were not significantly shifting over the study periods in all the sampled stations.

3.1.4. Warmest Night (TNx) and Coldest Night (TNn). The trend in the warmest night $(\mathrm{TNx})$ is significantly increasing in all AEZs $(p<0.001)$. In line with this, significant increase in warm nights was also reported in previous studies $[36,62]$. The magnitude of change was reported to be $0.055^{\circ} \mathrm{C} /$ year for the lowland $\mathrm{AEZ}, 0.037^{\circ} \mathrm{C} /$ year for the midland $\mathrm{AEZ}$, and $0.063^{\circ} \mathrm{C} /$ year for the highland $\mathrm{AEZ}$. In relative terms, the highland AEZ has experienced higher magnitude of change in the TNx than both the midland and lowland AEZs (Table 3). The temperature of the coldest night (TNn) during the observation periods has increased significantly in all AEZs $(p<0.001)$. The magnitude of change in the TNn was reported to be $0.078^{\circ} \mathrm{C} /$ year in the lowland $\mathrm{AEZ}, 0.075^{\circ} \mathrm{C} /$ year in the midland $\mathrm{AEZ}$, and $0.084^{\circ} \mathrm{C} /$ year in the highland AEZ $(p<0.001)$, respectively. Similar to the higher magnitude of change observed in the $\mathrm{TNx}$ in the 


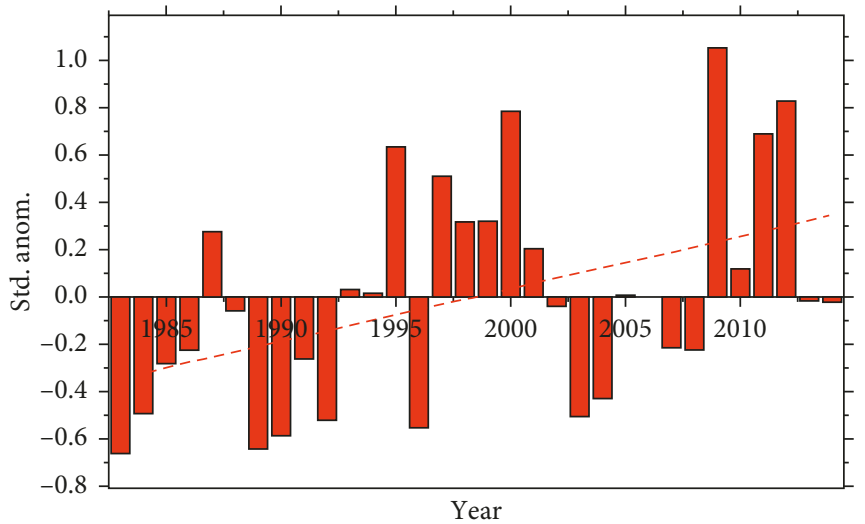

(a)

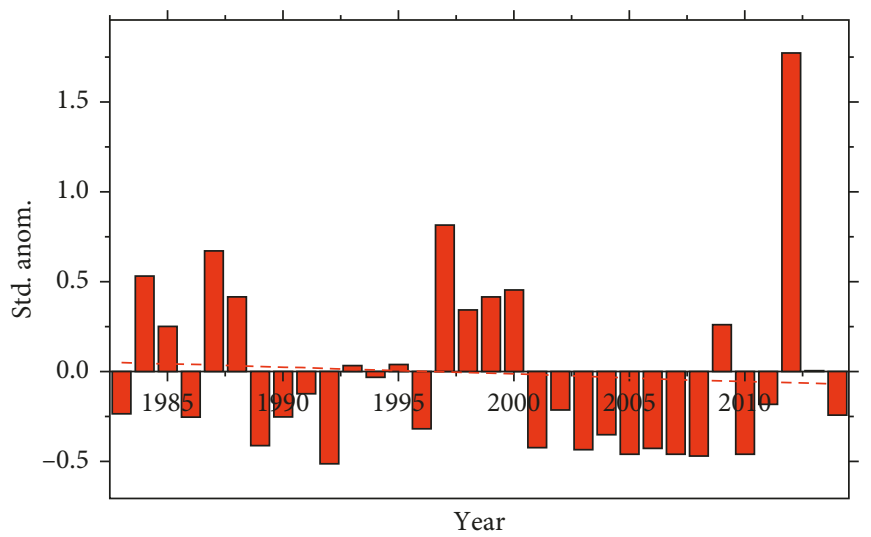

(c)

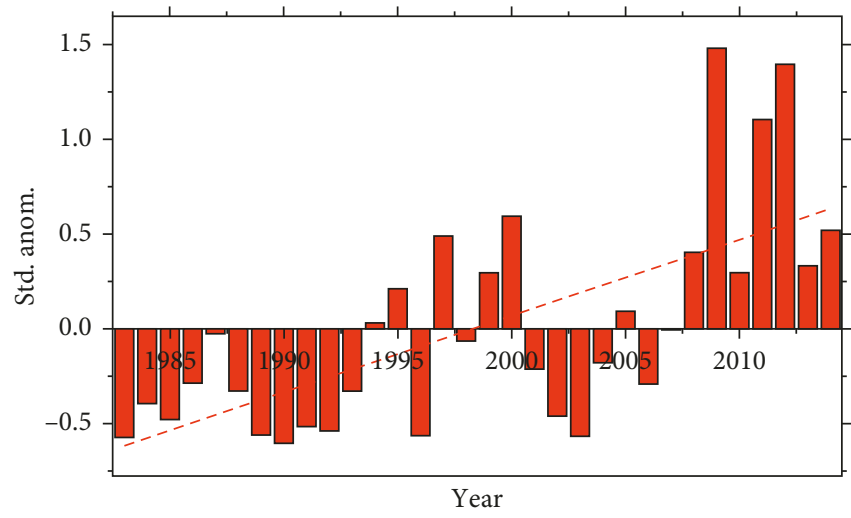

(e)

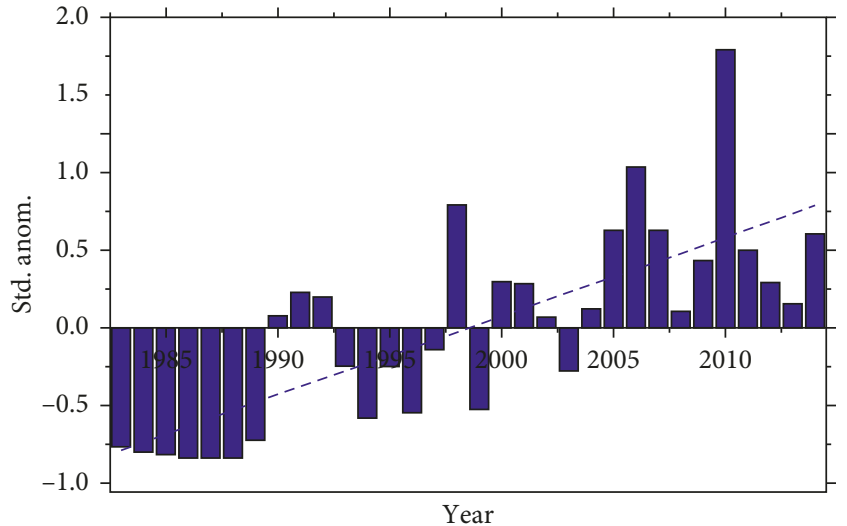

(b)

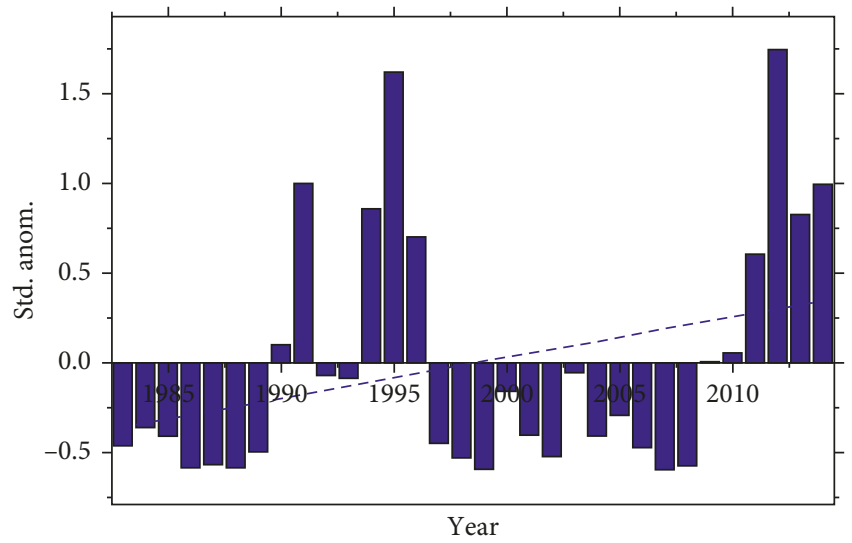

(d)

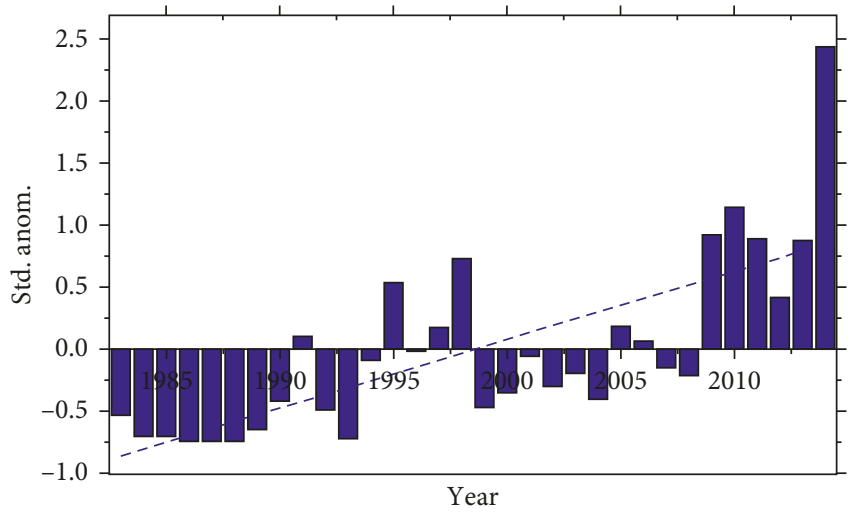

(f)

FIGURE 2: Standardized anomalies of warm days (TX90p) over three agroecological zones, (a) lowland, (c) midland, and (e) highland, and for warm nights (TN90p), (b) lowland, (d) midland, and (f) highland, for the period 1983-2014.

highland AEZ, the magnitude of change in TNn is slightly higher than the two AEZs. The anomalies of the TNx and TNn are shown in Figure 5. The TNx's highest positive value was observed in 2006 (Figure 5(a)), in 2012 (Figure 5(c)), and in 2014 (Figure 5(e)) for the lowland, midland, and highland AEZs, respectively. On the contrary, the negative anomalies of the TNn were commonly observed in the 1980s across all AEZs, while the positive anomalies have been increasing from the 1990s onwards in all AEZs (Figures 5(b), 5(d), and $5(f))$.
In summary, the TXx in the midland AEZ showed a statistically significant decreasing trend of $0.017^{\circ} \mathrm{C} /$ year $(p<0.05)$, which is the only AEZ that experienced a decline in the trends of temperature indices (TXx, TXn, TNx, and TNn) computed for all AEZs. The higher magnitude of change in temperature extremes in the highland AEZ compared to the two other AEZs may have adverse impacts on the livelihoods of the highlanders. For example, there is evidence that continued incidence of meteorological drought episodes and famines have resulted in human and 


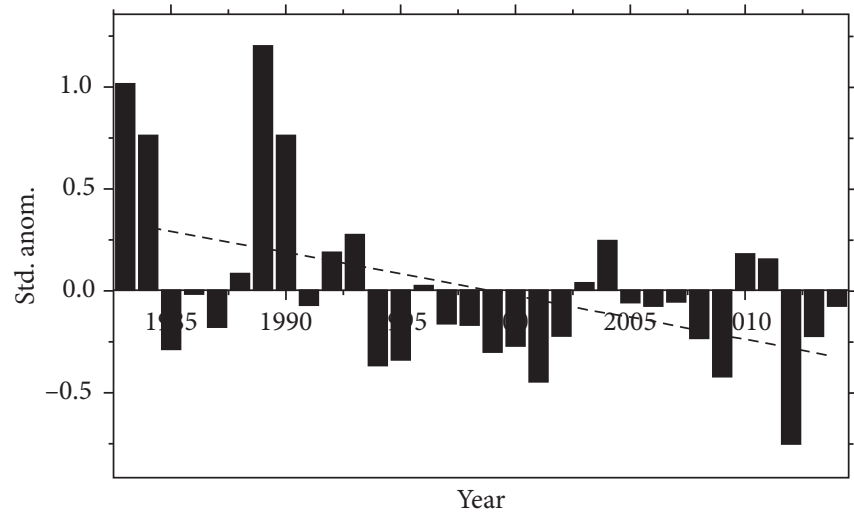

(a)

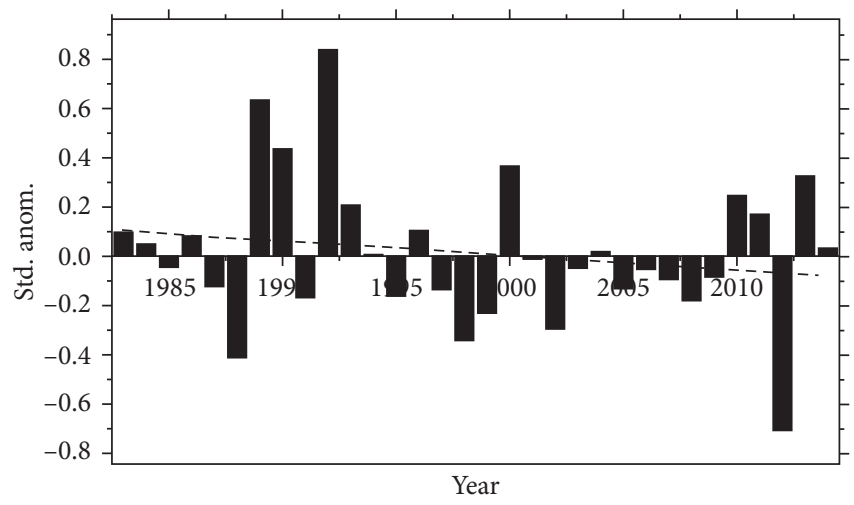

(c)

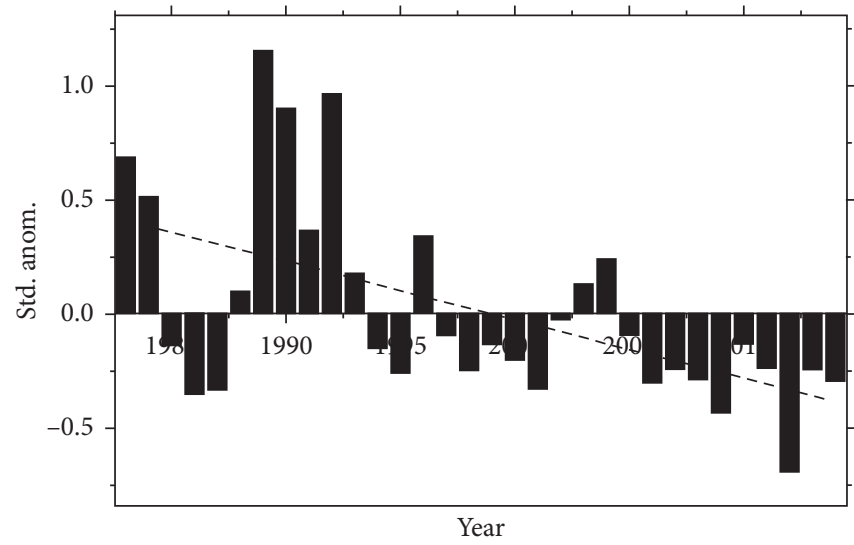

(e)

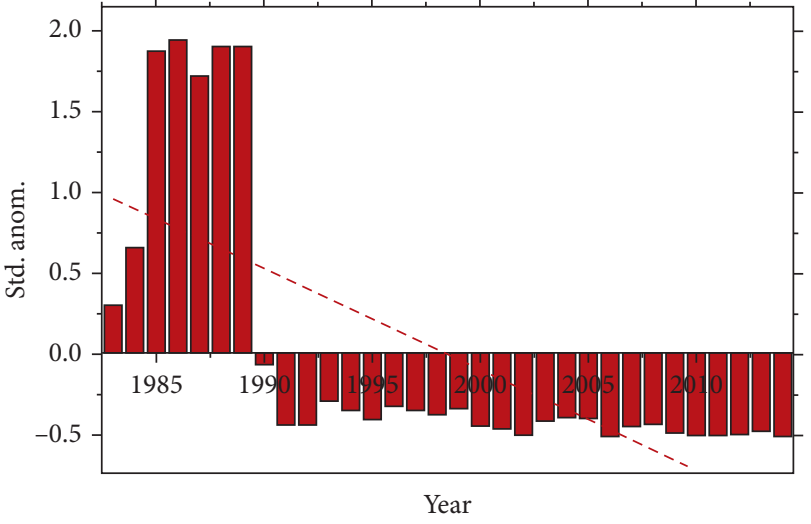

(b)

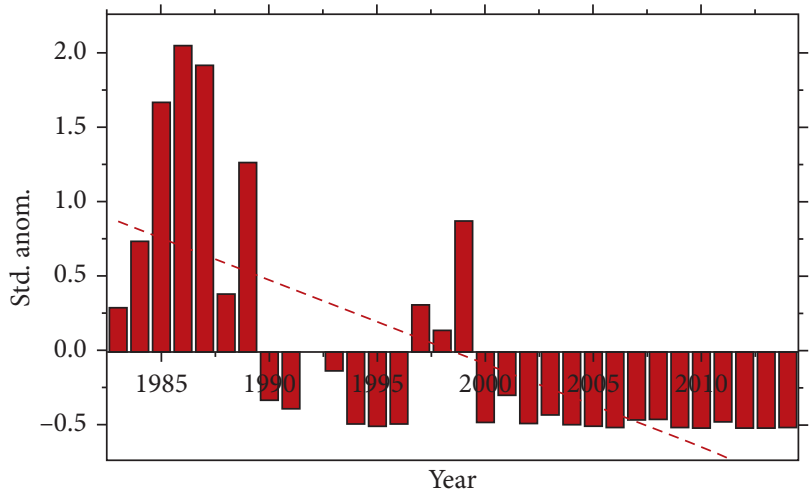

(d)

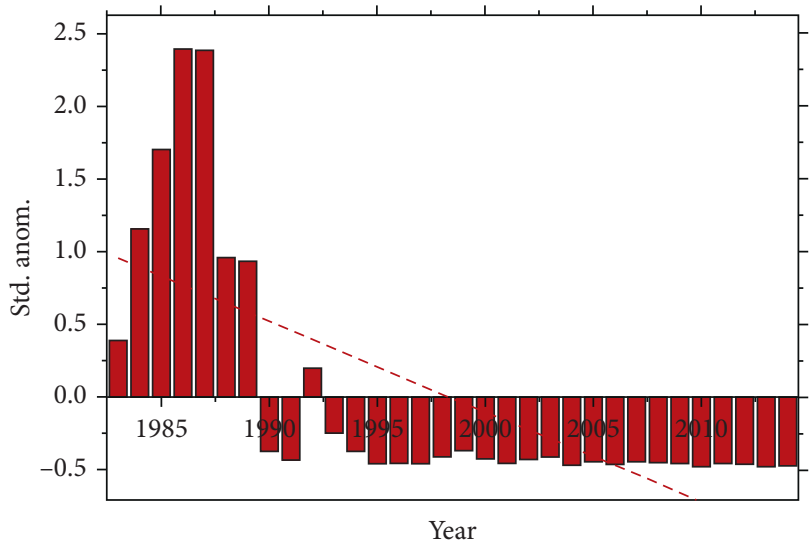

(f)

Figure 3: Standardized anomalies of cool days (TX10p) over three agroecological zones, (a) lowland, (c) midland, and (e) highland, and for cool nights (TN10p), (b) lowland, (d) midland, and (f) highland, for the period 1983-2014.

crop diseases, particularly in the northern highland regions of Ethiopia [63-66]. Generally, the recent IPCC projection noted that changing climatic variability will possibly result in more extreme events including flooding and drought [3], signifying that the negative impacts of climate trends have been more common than positive ones [1].

3.1.5. Warm Spell Duration Indicator (WSDI) and Cold Spell Duration Indicator (CSDI). The warm spell duration indicator (WSDI) index which represents the number of days contributing to a warm period was statistically insignificant in all AEZs. However, a significantly decreasing trend was observed in the cold spell duration indicator (CSDI) in all AEZs. The CSDI values show a decrease of 0.667 days/year in the lowland AEZ, 2.259 days/year in the midland AEZ, and 1 day/year in highland AEZ (Table 3). In relative terms, the CSDI is higher in the midland AEZ than in the lowland and highland AEZs. Similar trends were reported by Mekasha et al. [31] for WSDI and CSDI. The CSDI revealed significantly decreasing trend in all AEZs, suggesting that the AEZs are getting warmer although WSDI is not statistically 


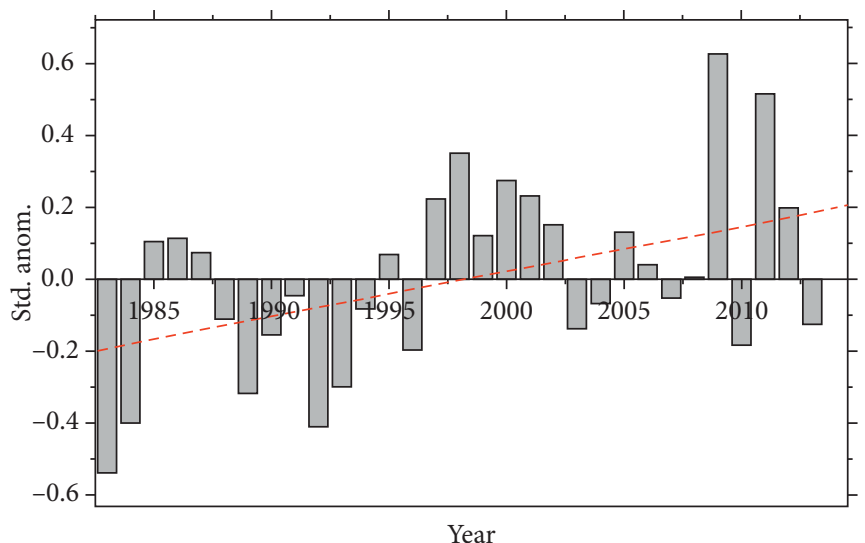

(a)

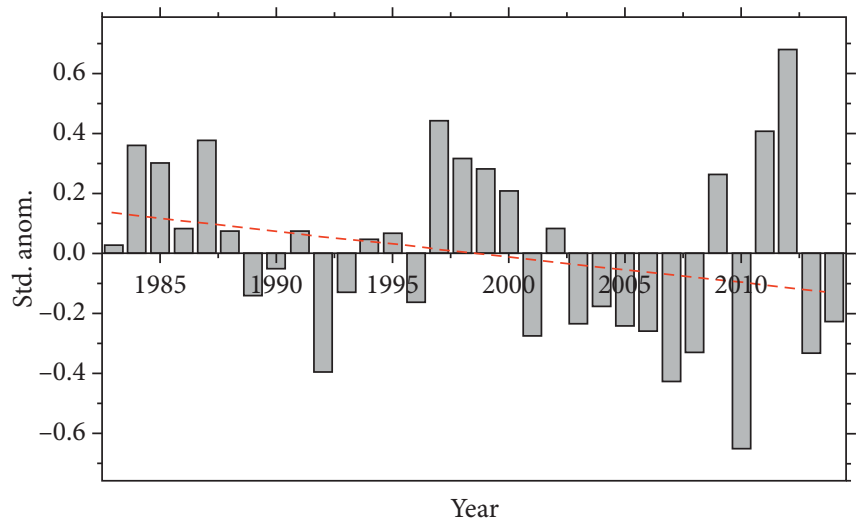

(c)

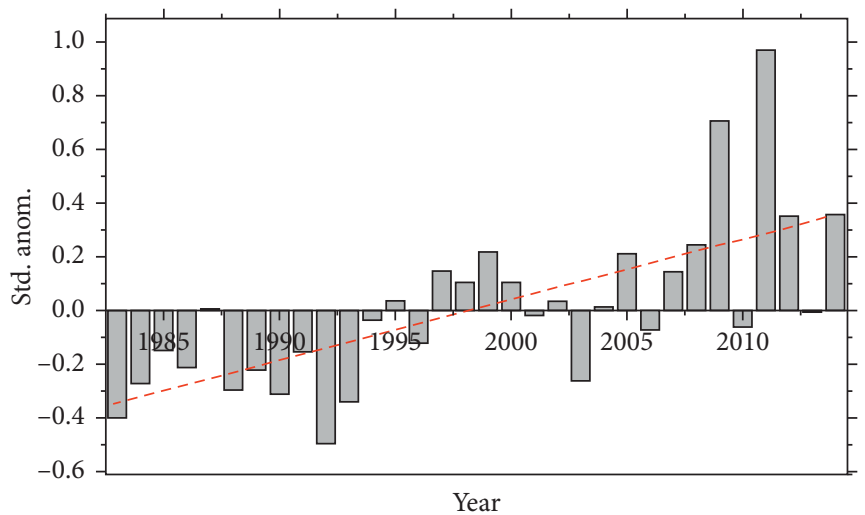

(e)

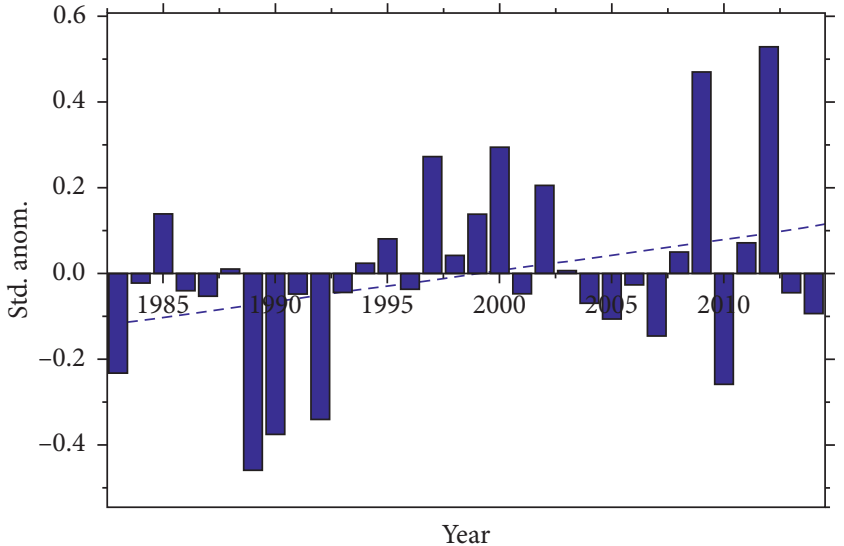

(b)

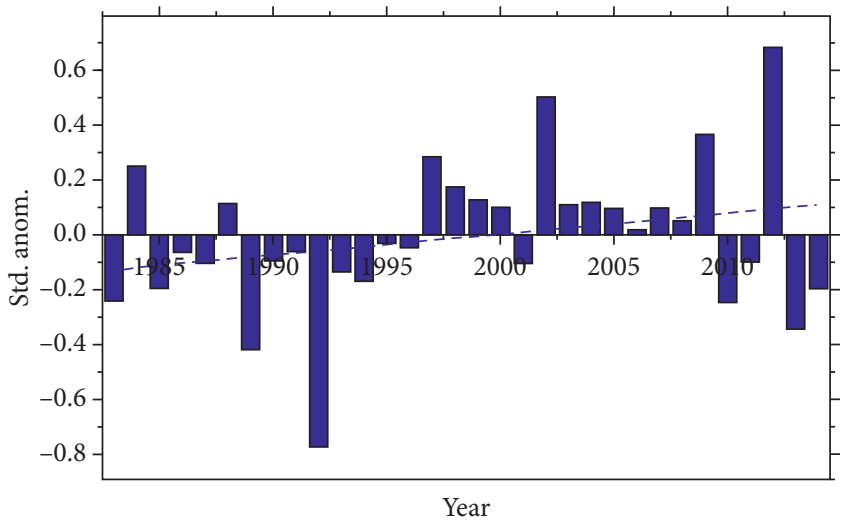

(d)

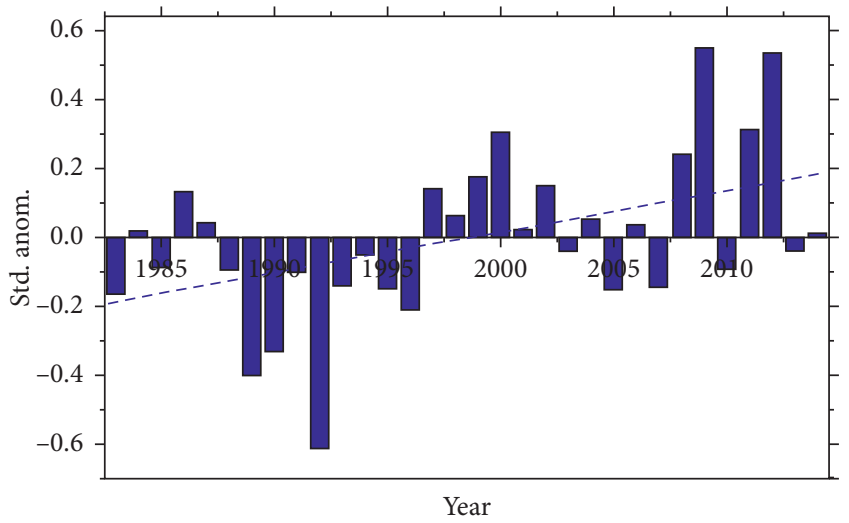

(f)

Figure 4: Standardized anomalies of the warmest day (TXx) over three agroecological zones, (a) lowland, (c) midland, and (e) highland, and for the coldest day (TXn), (b) lowland, (d) midland, and (f) highland, for the period 1983-2014.

significant in the same AEZs. The decrease in CSDI is in agreement with the observed warming in other studies such as the study by Donat et al. [60] carried out across the globe. However, the recent trends for CSDI and WSDI were mixed in the Upper Blue Nile Basin [36], which also suggests contextual differences between the current and previous studies.

3.1.6. Diurnal Temperature Range (DTR). With regards to the trend in the DTR, all AEZs have experienced significantly decreasing trend (Table 3 ). The magnitude of change of DTR was $-0.052^{\circ} \mathrm{C} /$ year and $-0.043^{\circ} \mathrm{C} /$ year $(p<0.05)$ in the lowland and highland AEZs, respectively. A very significant decreasing trend in the DTR of the midland AEZ was observed $\left(0.053^{\circ} \mathrm{C} /\right.$ year $)$ $(p<0.001)$ (Figure 6(b)). Similarly, Mekasha et al. [31] reported a significantly decreasing trend in DTR only in Negele Borena station in Ethiopia. Moreover, Zhou et al. [67] documented that there has been a decreasing trend in DTR in some other parts of the world, mainly in arid 


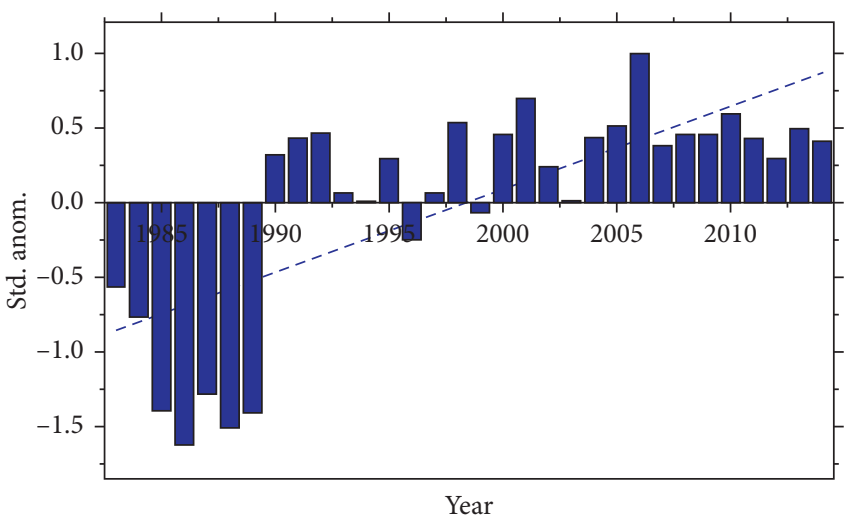

(a)

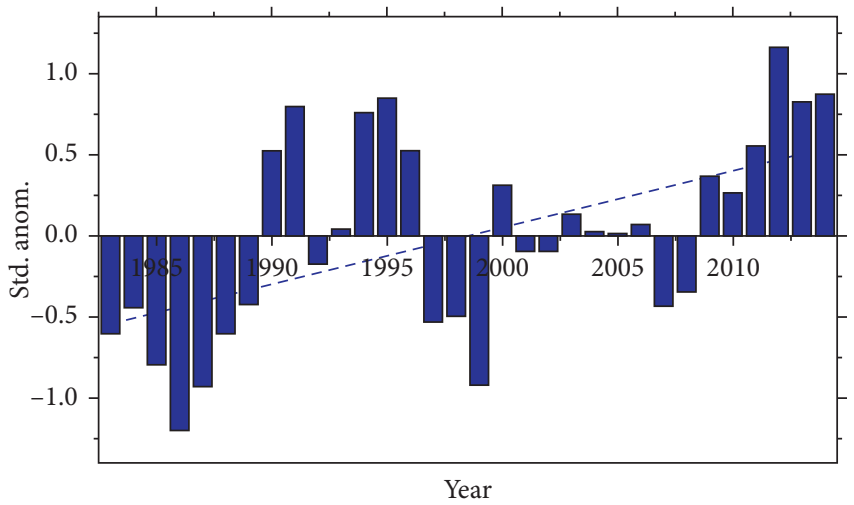

(c)

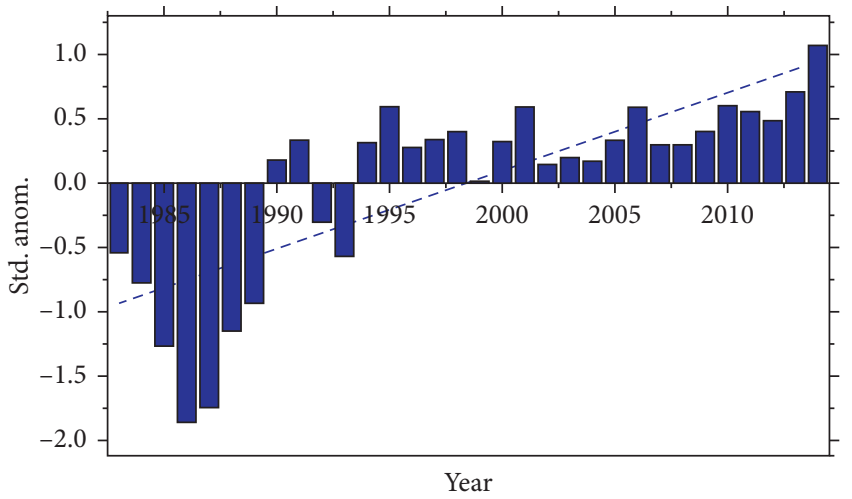

(e)

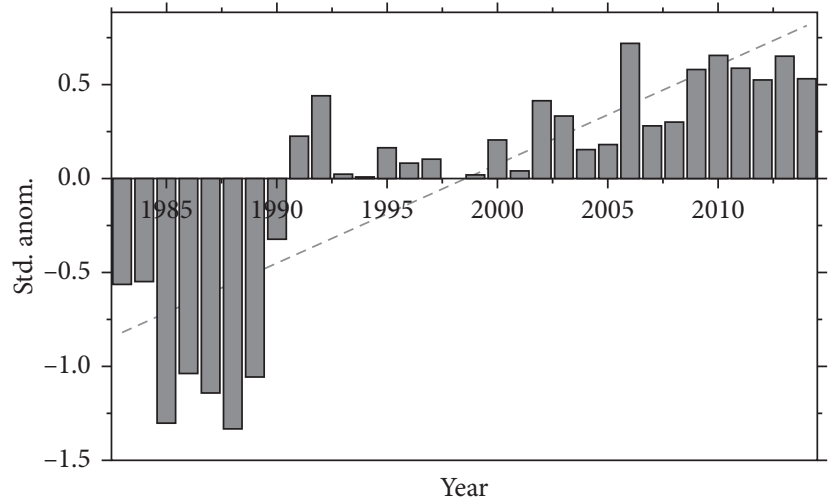

(b)

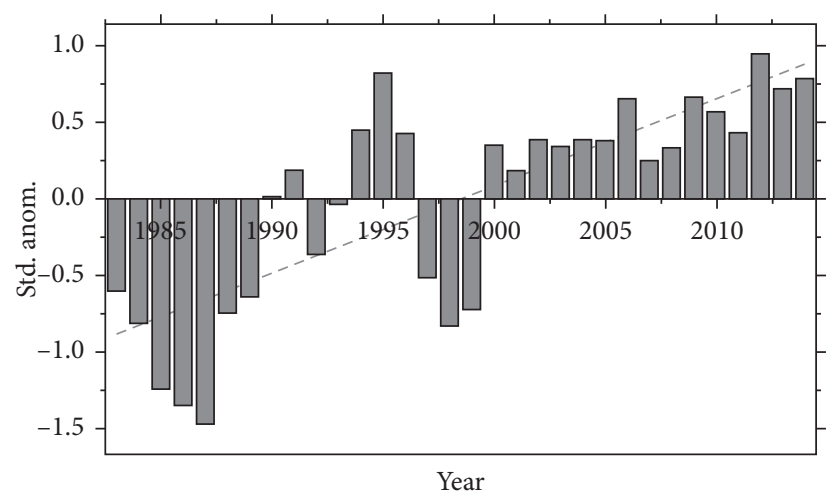

(d)

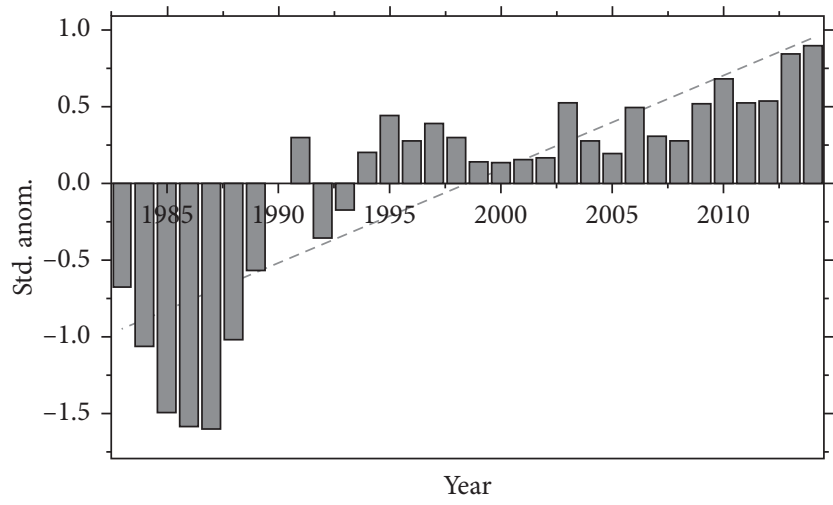

(f)

Figure 5: Standardized anomalies of the warmest night (TNx) over three agroecological zones, (a) lowland, (c) midland, and (e) highland, and for the coldest night (TNn), (b) lowland, (d) midland, and (f) highland, for the period 1983-2014.

and semiarid regions. Concurring to this, the mean annual DTR exhibited a reduction by 0.5 to $1^{\circ} \mathrm{C}$ in Sudan and Ethiopia between the 1950s and 2000 [68].

A decrease in DTR suggests that the trend in the daily maximum temperature is smaller than the trend in the daily minimum temperature. Earlier studies reported on the relevance of DTR as one of the proxy indicators for climate change. For example, a study by Makowski et al. [69] considered DTR as the important indicator of climate change.

\subsection{Trends in Precipitation Extremes}

3.2.1. Simple Daily Intensity Index (SDII), Consecutive Dry Days (CDD), and Consecutive Wet Days (CWD). The SDII, which monitors precipitation intensity on wet days, did not show any significant trend in all AEZs, a finding that is in line with results from $[25,31,36]$. The highest SDII was recorded in 2013 in the lowland (Figure 7(a)), in 2012 in the midland (Figure 7(b)), and in 2005 in the highland AEZ (Figure 7(c)), respectively. By the same token, the trend analysis of both consecutive dry days (CDD) and 


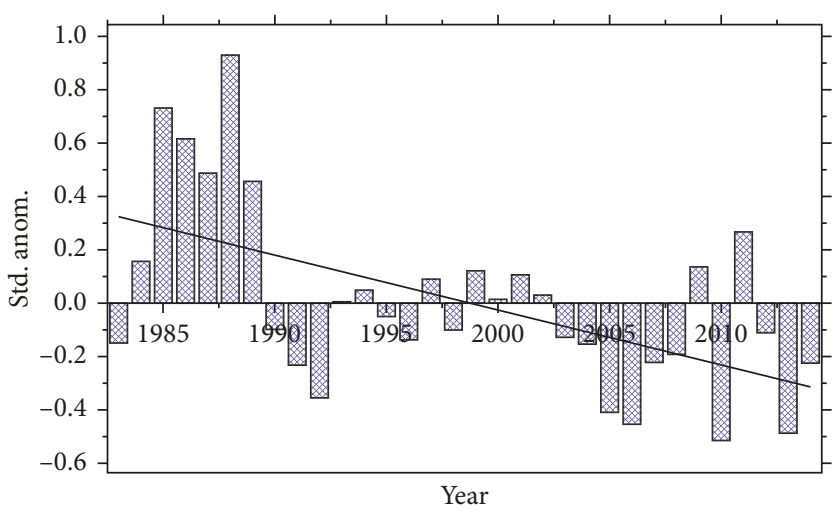

(a)

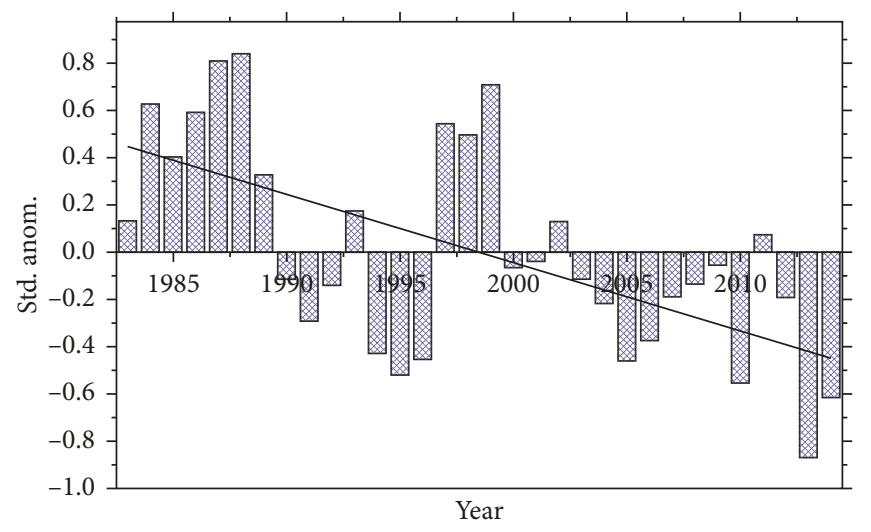

(b)

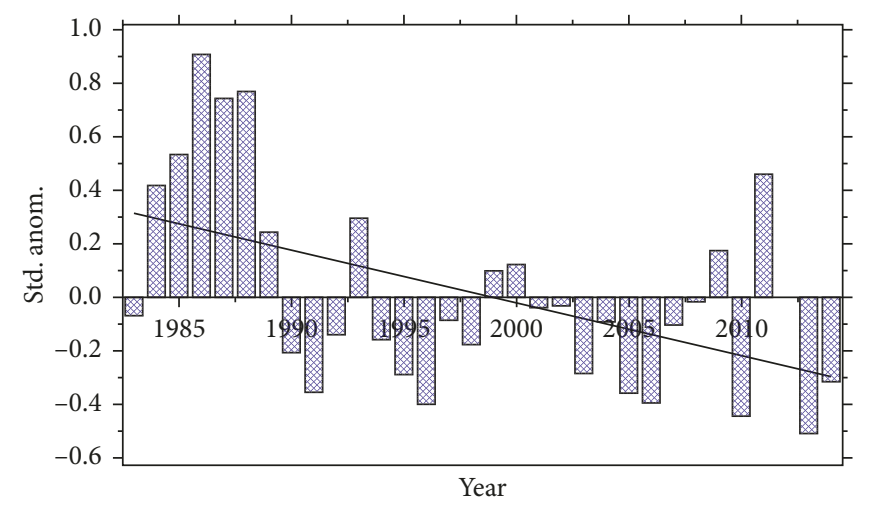

(c)

FIGURE 6: Standardized anomalies of the diurnal temperature range (DTR) over three agroecological zones, (a) lowland, (b) midland, and (c) highland, for the period 1983-2014.

consecutive wet days (CWD) imply that the results were not significant in all AEZs (Table 4). The highest CDD was observed in 2012 in the lowland (Figure 8(a)), in 2008 in the midland (Figure 8(c)), and in 2000 in highland AEZs (Figure 8(e)),respectively. On the contrary, the highest CWD was observed in the years between 1988 and 1997 in the lowland (Figure 8(b)), in 1992 in the midland (Figure 8(d)), and in 1987 in the highland AEZs (Figure 8(f)), respectively. Although insignificant trends were observed in the CDD and CWD, the early 1990s were wet years compared to the 2000s, which signify warming over the studied AEZs. The same trend was documented by previous studies such as [25, 31, 36]. However, Mekasha et al. [31] observed a decreasing trend for CDD in one station. A study by Mengistu et al. [48] reported that agroecological zones in the Upper Blue Nile River Basin experienced relatively cold years in the 1980s and warm years from the early 1990s to the 2000s.

3.2.2. Number of Heavy (R10mm) and Very Heavy (R20mm) Precipitation Days. The number of very heavy precipitation days (R20mm) was increasing with a magnitude of 0.325 days/year $(p<0.05)$ in the midland AEZ but was insignificant in the other AEZs. The highest R20mm was recorded in the year 2013 in the lowland (Figure 9(b)), in
2012 in the midland (Figure 9(d)), and in 1988 in the highland AEZs (Figure 9(f)), respectively. The increasing trend in the rainfall amount in the midland AEZ was in line with recent findings from Degefu and Bewket [38] in which Wolaita Sodo, as one of the meteorological stations, was found to experience an increasing trend in the average annual total rainfall $(p<0.01)$. Similarly, a recent study by Weldegerima et al. [70] in Northern Ethiopia has documented an increase in annual rainfall with the magnitude of change being 2.20, 3.42, 6.58, and $2.88 \mathrm{~mm} /$ year, in Bahir Dar, Dangila, Debre Tabor, and Gondar, respectively. On the contrary, insignificant decreasing trend was reported both in the lowland and in the highland AEZs in R10mm while it was insignificant increasing trend in the midland AEZ. The highest R10mm was recorded in the year 1987 in the lowland (Figure 9(a)), in 2006 in the midland (Figure 9(c)), and in 2007 in the highland AEZs (Figure 9(e)), respectively. In general, the midland AEZ shows both significant and insignificant increasing trends in the $R 20 \mathrm{~mm}$ and $\mathrm{R} 10 \mathrm{~mm}$ between 1983 and 2014. The variations in the years of highest $\mathrm{R} 10 \mathrm{~mm}$ and $\mathrm{R} 20 \mathrm{~mm}$ suggest the trend differences between and among the AEZs.

3.2.3. Maximum 1-Day (RX1day) and 5-Day (RX5day) Precipitations. The trend of maximum 1-day precipitation 


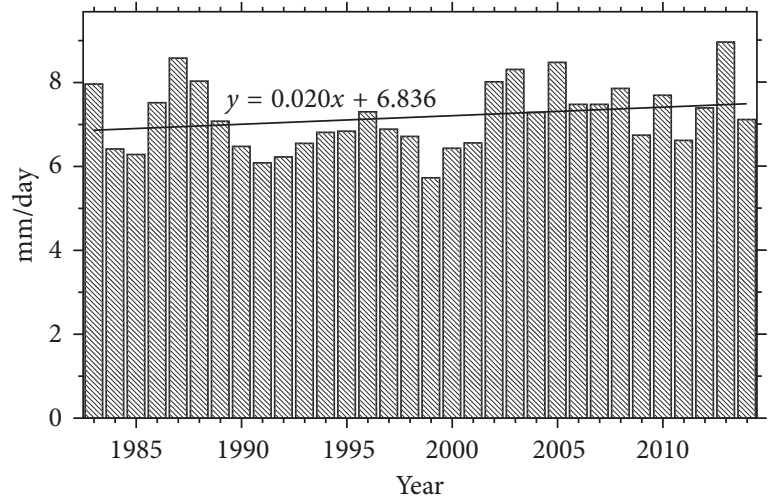

(a)

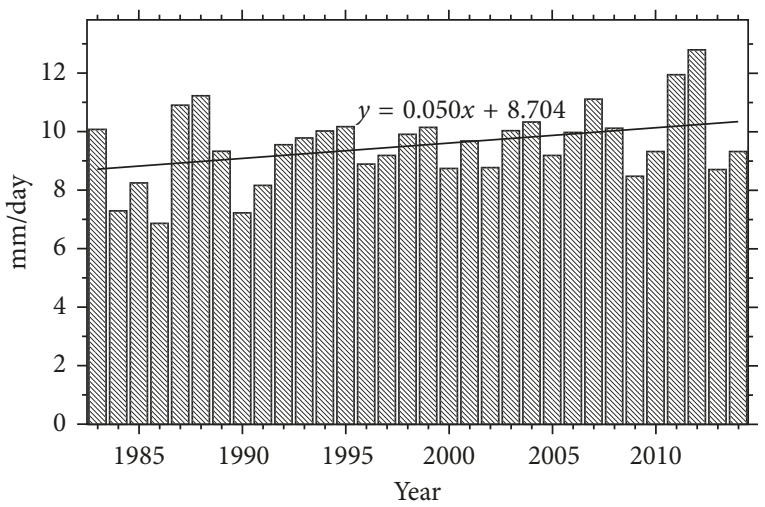

(b)

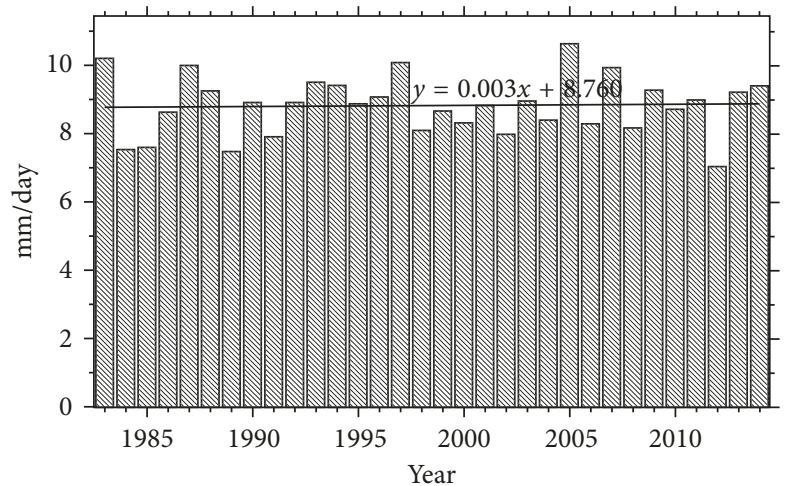

(c)

Figure 7: Trend of the simple daily intensity index (SDII) over three agroecological zones, (a) lowland, (b) midland, and (c) highland, for the period 1983-2014.

TABLE 4: Trends in precipitation extreme indices per year by AEZ.

\begin{tabular}{|c|c|c|c|c|c|c|c|}
\hline \multirow{2}{*}{ Index } & \multirow{2}{*}{ Units } & \multicolumn{2}{|c|}{ Lowland AEZ } & \multicolumn{2}{|c|}{ Midland AEZ } & \multicolumn{2}{|c|}{ Highland AEZ } \\
\hline & & MK test ( $Z$-test) & Sen's slope & MK test (Z-test) & Sen's slope & MK test (Z-test) & Sen's slope \\
\hline SDII & $\mathrm{mm} /$ day & $0.190^{\mathrm{ns}}$ & $0.026^{\mathrm{ns}}$ & $0.185^{\mathrm{ns}}$ & $0.044^{\mathrm{ns}}$ & $0.044^{\mathrm{ns}}$ & $0.006^{\mathrm{ns}}$ \\
\hline CDD & Days & $-0.085^{\mathrm{ns}}$ & $-0.396^{\mathrm{ns}}$ & $-0.028^{\mathrm{ns}}$ & $-0.089^{\mathrm{ns}}$ & $0.020^{\mathrm{ns}}$ & $0.118^{\text {ns }}$ \\
\hline CWD & Days & $-0.124^{\mathrm{ns}}$ & $-0.049^{\mathrm{ns}}$ & $-0.103^{\mathrm{ns}}$ & $-0.04^{\mathrm{ns}}$ & $-0.159^{\mathrm{ns}}$ & $-0.017^{\mathrm{ns}}$ \\
\hline $\mathrm{R} 10 \mathrm{~mm}$ & Days & $-0.045^{\mathrm{ns}}$ & $-0.057^{\mathrm{ns}}$ & $0.053^{\mathrm{ns}}$ & $0.137^{\mathrm{ns}}$ & $-0.060^{\mathrm{ns}}$ & $-0.041^{\mathrm{ns}}$ \\
\hline $\mathrm{R} 20 \mathrm{~mm}$ & Days & $0.198^{\mathrm{ns}}$ & $0.078^{\mathrm{ns}}$ & $0.331^{*}$ & $0.325^{*}$ & $0.010^{\mathrm{ns}}$ & $0.00^{\mathrm{ns}}$ \\
\hline RX1day & $\mathrm{mm}$ & $0.171^{\mathrm{ns}}$ & $0.143^{\mathrm{ns}}$ & $0.059^{\text {ns }}$ & $0.092^{\text {ns }}$ & $0.295^{*}$ & $0.297^{*}$ \\
\hline RX5day & $\mathrm{mm}$ & $0.067^{\text {ns }}$ & $0.111^{\mathrm{ns}}$ & $0.175^{\text {ns }}$ & $0.728^{\text {ns }}$ & $-0.067^{\mathrm{ns}}$ & $-0.143^{\mathrm{ns}}$ \\
\hline R95p & $\mathrm{mm}$ & $0.188^{\text {ns }}$ & $2.418^{\text {ns }}$ & $0.275^{*}$ & $6.048^{*}$ & $0.244^{\mathrm{ns}}$ & $2.757^{*}$ \\
\hline $\mathrm{R} 99 \mathrm{p}$ & $\mathrm{mm}$ & 0.188 & $0.00^{\text {ns }}$ & $0.052^{\mathrm{ns}}$ & $0.00^{\mathrm{ns}}$ & $0.201^{\mathrm{ns}}$ & $0.125^{\text {ns }}$ \\
\hline
\end{tabular}

ns: nonsignificant, $p>0.05 ;{ }^{*} p \leq 0.05 ;{ }^{* *} p \leq 0.01 ;{ }^{* * *} p \leq 0.001$.

amount (RX1day) was observed to increase in the highland AEZ with a magnitude of $0.297 \mathrm{~mm} /$ year $(p<0.05)$. On the contrary, both the lowland and midland AEZs have experienced insignificant trend in the RX1day. The maximum RX1day was recorded in the year 2005 in the lowland (Figure 10(a)), in 1988 in the midland (Figure 10(c)), and in 2014 in the highland AEZs (Figure 10(e)), respectively. An insignificant positive trend in the RX5 day was reported both in the lowland and midland AEZs, while it was a negative trend in the highland AEZ (Table 4). In relation to the maximum RX5 day, it was recorded in 2008 in the lowland (Figure 10(b)), in the years of 1987 and 2007 in the midland
(Figure 10(d)), and in 2011 in the highland AEZs (Figure 10(f)), respectively. In summary, with the exception of the highland AEZ for RX1day, all AEZs have experienced insignificant trend both in the RX1day and RX5 day. On the contrary, Worku et al. [36] found out that significant increasing trend was observed in the Rx5 day in Fichie and Mendida stations, while significant decreasing trend was observed in the Rx1day in Alem ketema station in the Upper Blue Nile Basin.

3.2.4. Very Wet Days (R95p) Extremely Wet Days (R99p). The trend of R95p was statistically significant both in the midland $(6.048 \mathrm{~mm} /$ year $)$ and highland AEZs $(2.757 \mathrm{~mm} /$ 


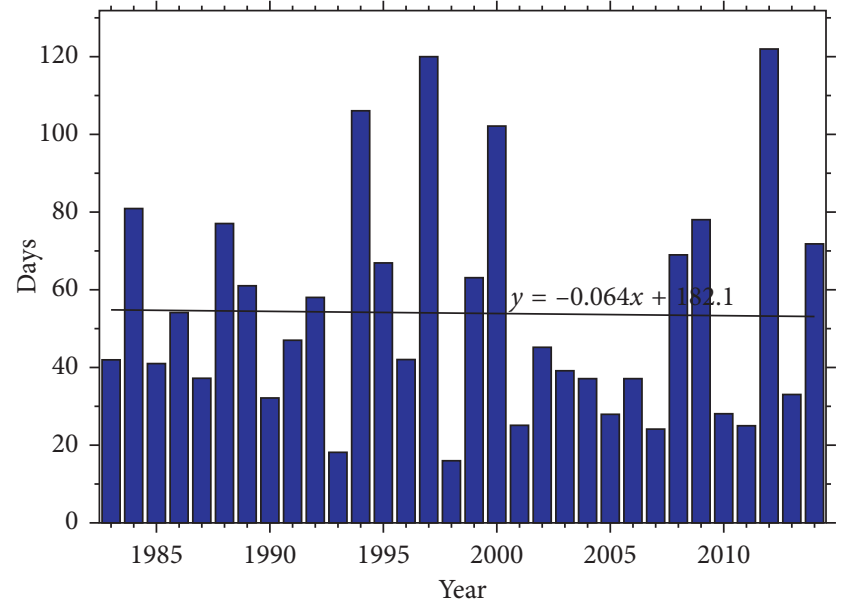

(a)

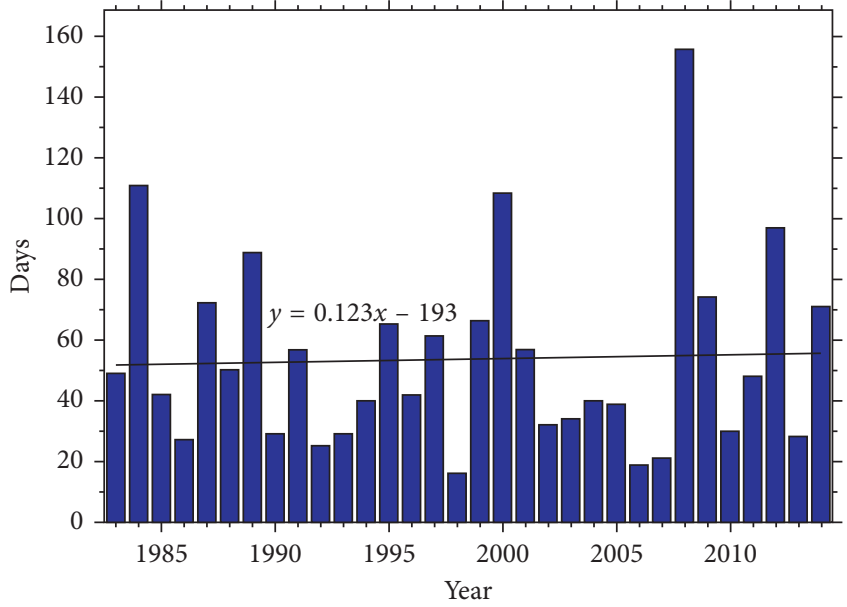

(c)

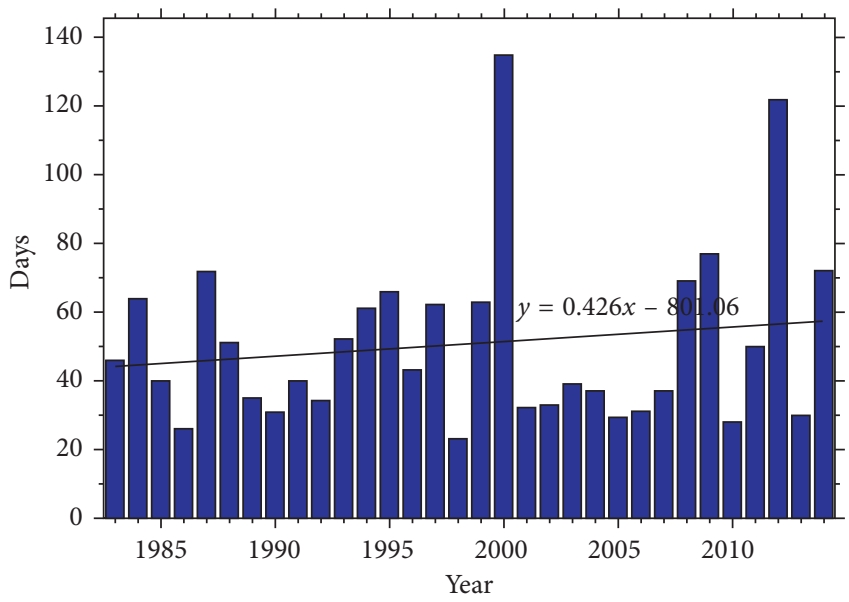

(e)

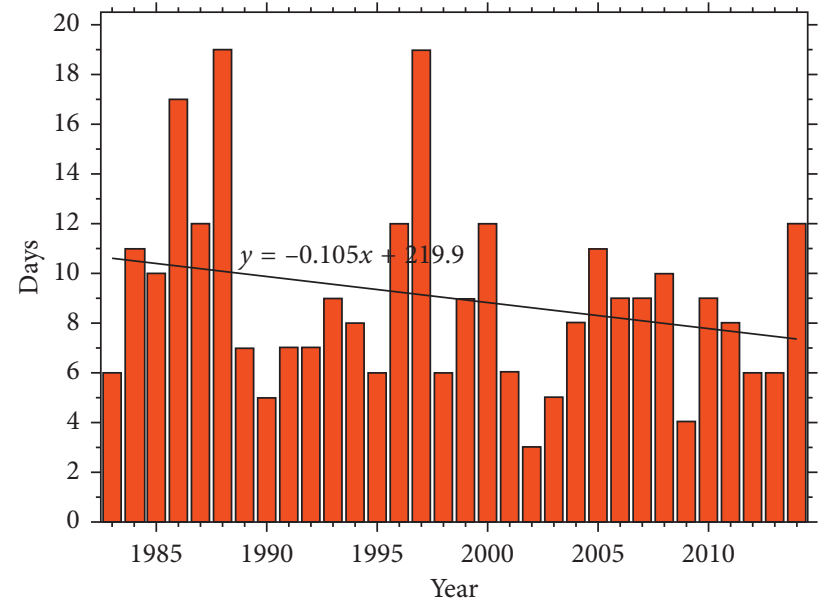

(b)

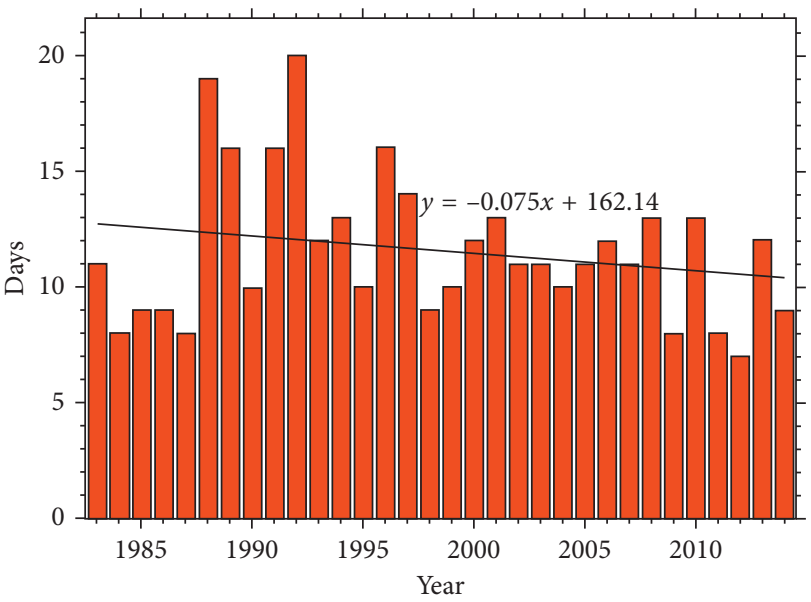

(d)

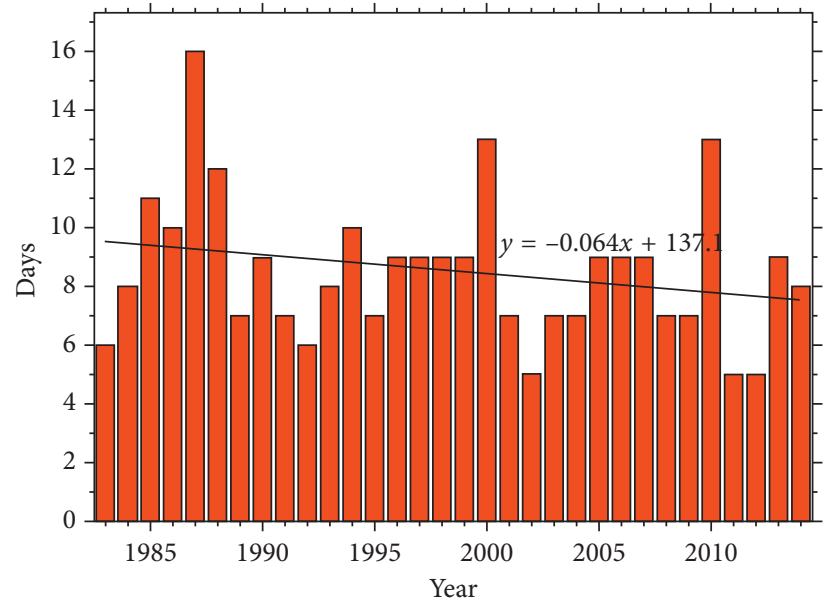

(f)

FIGURE 8: Trend of consecutive dry days (CDD) over three agroecological zones, (a) lowland, (c) midland, and (e) highland, and for consecutive wet days (CWD), (b) lowland, (d) midland, and (f) highland, for the period 1983-2014.

year) $(p<0.05)$. Insignificant increasing trend was observed in the lowland AEZ, suggesting a positive trend in very wet days in two of the AEZs. Similarly, insignificant increasing trend was observed for R99p across all AEZs. Nevertheless, with the continuing climate change and variability, precipitation in Ethiopia is expected to decline from a mean annual value of $2.04 \mathrm{~mm} /$ day (1961-1990) to $1.97 \mathrm{~mm} /$ day (2070-2099) with a total decline in rainfall by $25.5 \mathrm{~mm} /$ year [71]. On this future 


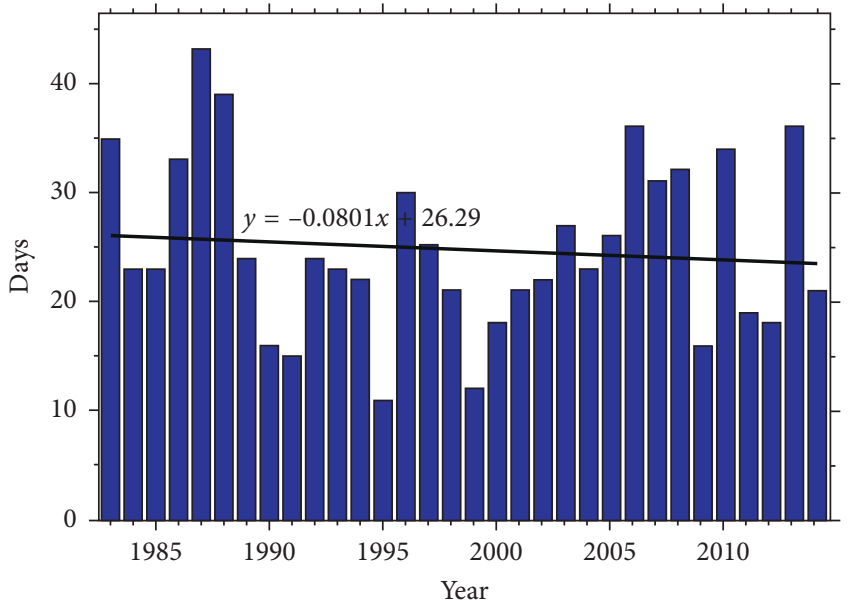

(a)

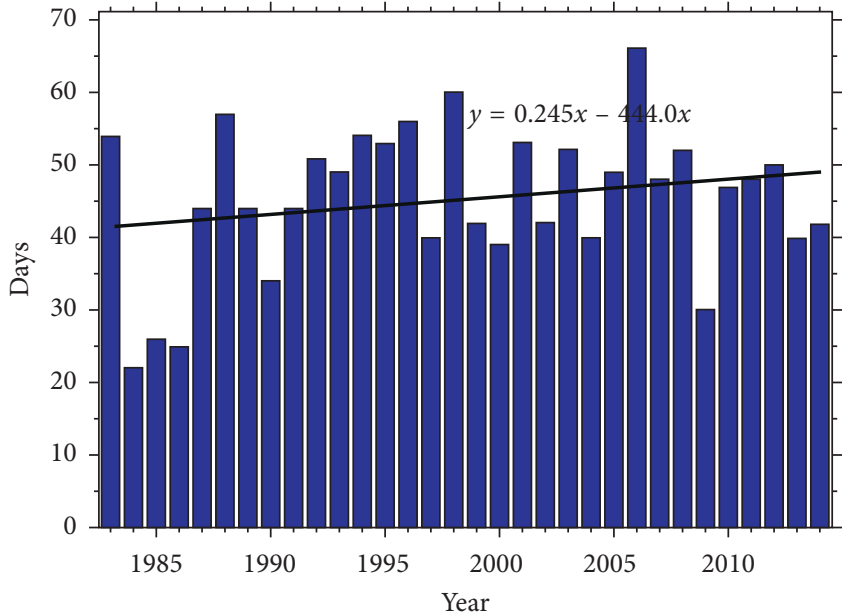

(c)

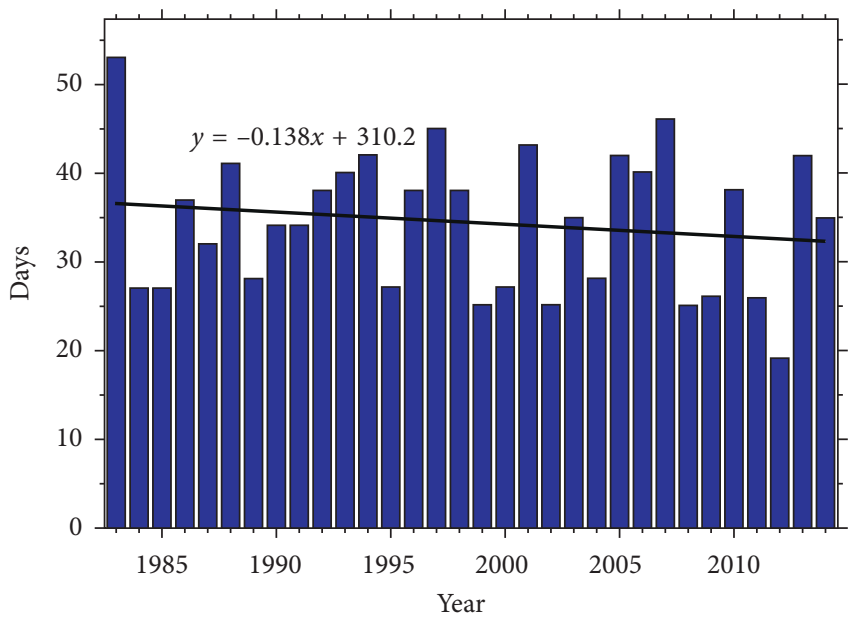

(e)

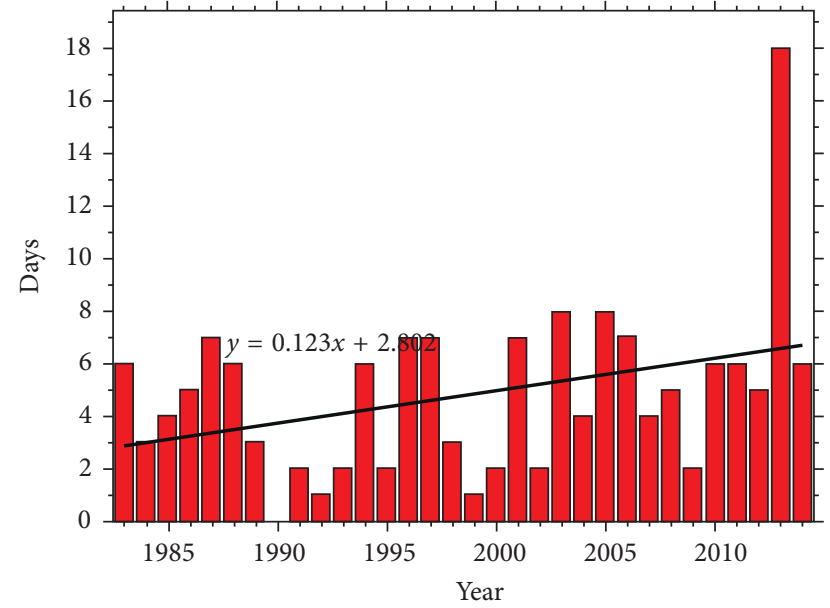

(b)

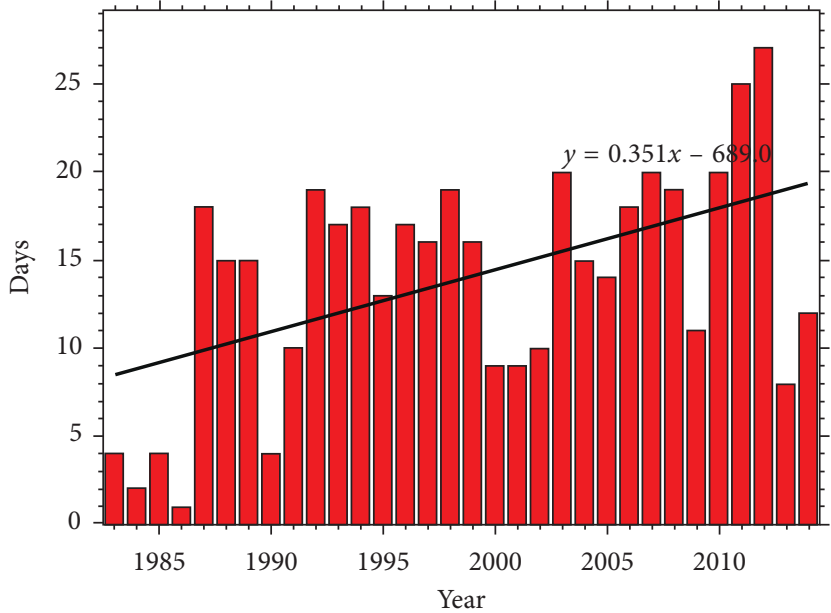

(d)

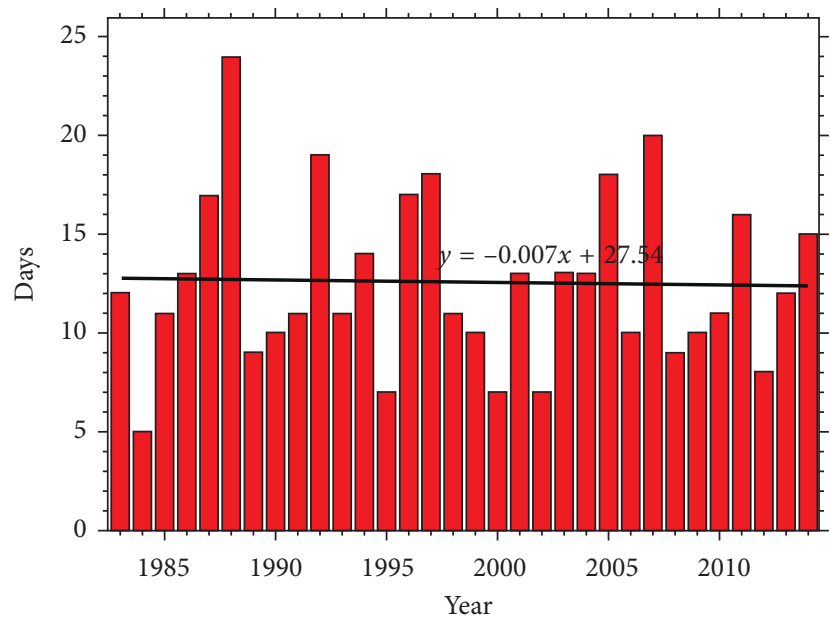

(f)

Figure 9: Trends of number of heavy precipitation days (R10mm) over three agroecological zones, (a) lowland, (c) midland, and (e) highland, and for number of very heavy precipitation days (R20mm), (b) lowland, (d) midland, and (f) highland, for the period $1983-2014$.

change, several climate change estimation scenarios and models confirm that many parts of Ethiopia are likely to experience a reduction in the length of the growing period with higher reductions in some parts of the country $[12,66]$. The observed trends in spatial and temporal variability in the climate extremes in the studied AEZs could be associated with the multiple topographic and relief structures of the country $[26,41]$. 


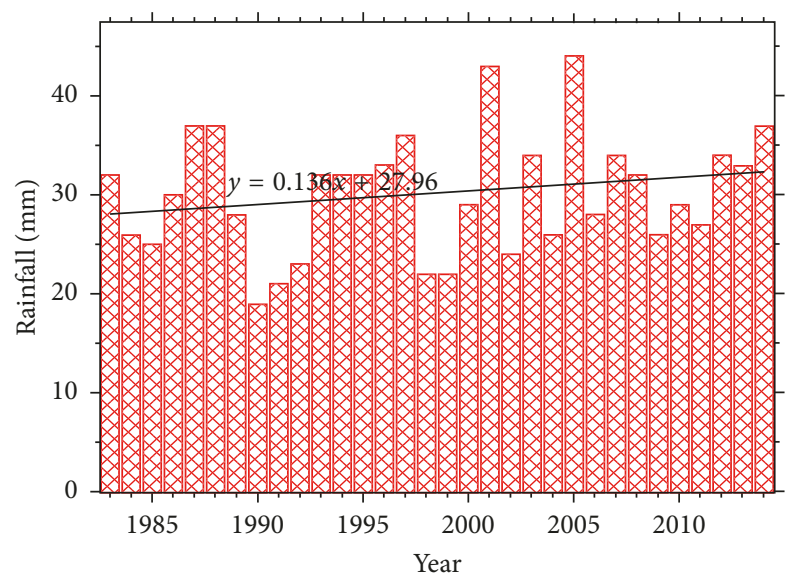

(a)

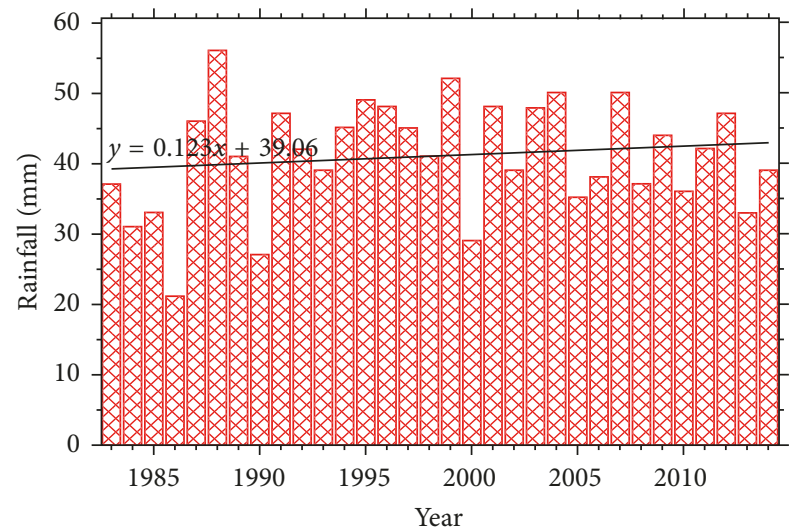

(c)

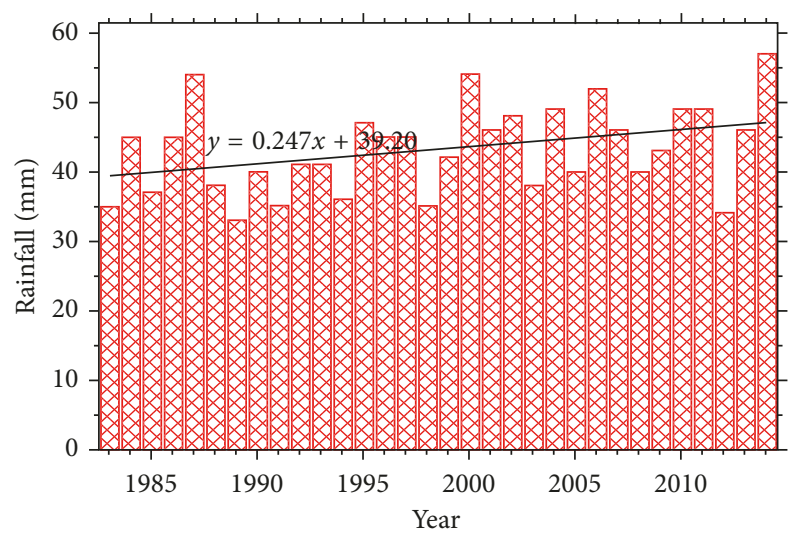

(e)

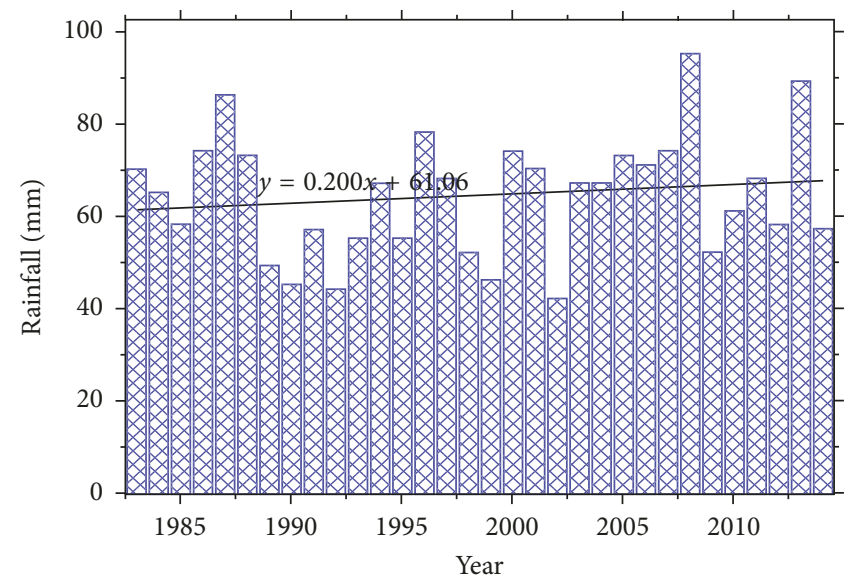

(b)

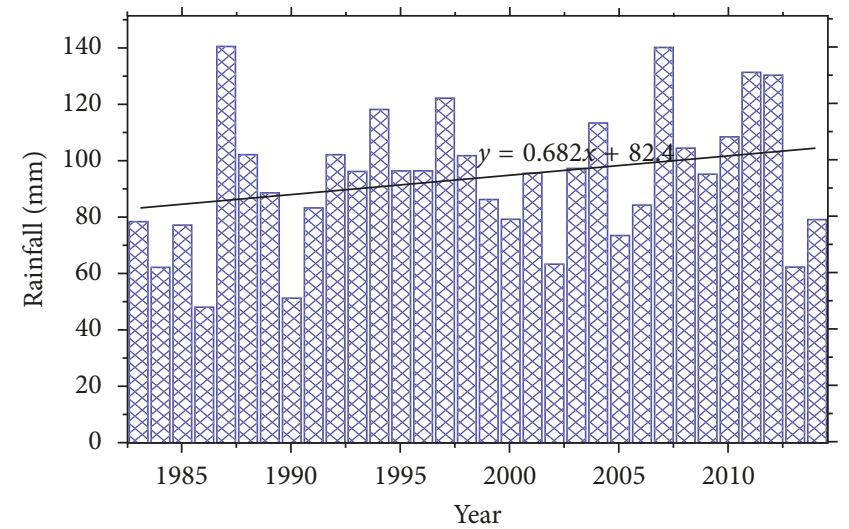

(d)

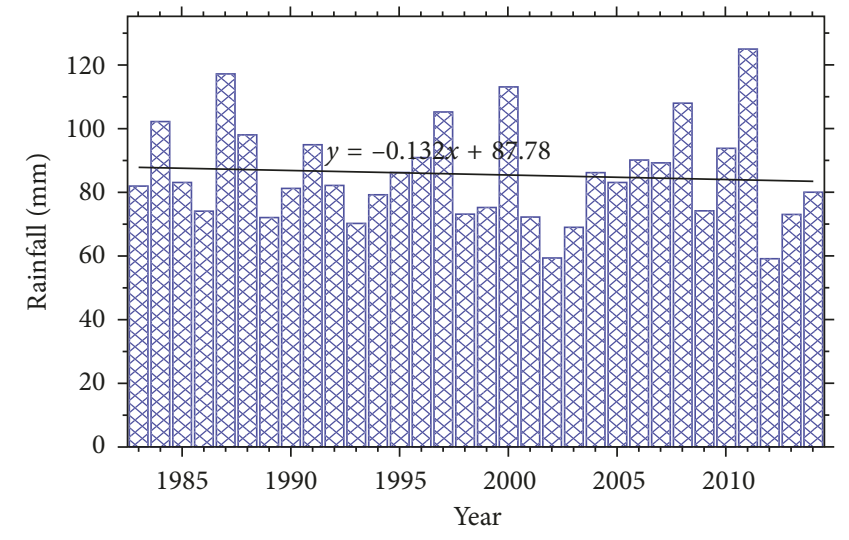

(f)

FIGURE 10: Trends of maximum 1-day precipitation (RX1day) over three agroecological zones, (a) lowland, (c) midland, and (e) highland, and for maximum 5-day precipitation (RX5 day), (b) lowland, (d) midland, and (f) highland, for the period 1983-2014.

In general, the extreme trend analysis confirmed that there is an overall propensity of increasing warm extremes and a decreasing tendency of cold extremes in the selected AEZs. The results are in line with similar findings reported in tropical environments where warm extremes showed increasing trends while the cold extremes showed decreasing trends [36, 41, 72].

\section{Conclusions}

This study has analyzed changes in the indices of extreme temperature and rainfall based on changes in duration, intensity, and frequency of climatic extremes in the lowland, midland, and highland AEZs in Wolaita Zone, Southern Ethiopia, over the period of 1983-2014. The 
trend analysis revealed that AEZs have experienced both positive and negative trends in temperature extremes. Overtime, the annual maximum value of daily maximum temperature (TXX), annual maximum value of daily minimum temperature (TNx), and annual minimum value of daily minimum temperature (TNn) have shown significant positive trends between 1983 and 2014, except in the midland where TXx deceased by $0.017^{\circ} \mathrm{C} /$ year. In terms of AEZ, the magnitude of change in temperature extremes is higher in the highland AEZ but lower in the midland AEZ, implying that the highland AEZ is experiencing a higher magnitude of change in the occurrence of climate extremes. This trend is likely to have adverse effects on the livelihoods of people in the highland agroecological zone. The annual number of occurrence of warm nights (TN90p) and the occurrence of warm days (TX90p) show significant warming anomalies for the period between 1983 and 2014 both in the lowland and highland AEZs. The occurrence of warm nights (TN90p) has shown a significant increasing trend $(p<0.001)$ in all AEZs except the midlands, which show insignificant increase in TN90p, while cool nights (TN10p) were consistently decreasing in all AEZs $(p<0.001)$. Insignificant decreasing trend in the frequency of cool days (TX10p) was observed both in the lowland and midland AEZs. TX10p shows a decreasing trend in the highland AEZ $(p<0.05)$. The warmest night (TNx) shows a significant increasing trend in all AEZs $(p<0.001)$. The magnitude of change in $\mathrm{TNx}$ is $0.055^{\circ} \mathrm{C}, 0.037^{\circ} \mathrm{C}$, and $0.063^{\circ} \mathrm{C} /$ year for the lowland, midland, and highland AEZs, respectively. Comparatively, the highland AEZ experienced a higher magnitude of change in the TNx than the midland and lowland AEZs. DTR shows a significant decreasing trend in all AEZs over the study period and indicating warming conditions.

Overall, the trends of warm extremes are increasing, and cold extremes are decreasing, implying a significant warming in the AEZs, which is in agreement with results from other studies in different geographic scales. A negative trend in the cold spell duration indicator (CSDI) was observed in all AEZs with magnitudes of change in CSDI being 0.667 days, 2.259 days, and 1 days/year for the lowland, midland, and highland AEZs, respectively. The trend was significant $(p<0.05)$ for both midland and highland AEZs and very significant for the lowland AEZ $(p<0.001)$. Even though the trends for consecutive dry days and consecutive wet days were insignificant in all AEZs, the number of very wet days has revealed a positive trend both in the midlands (6.048 days/year) and highlands ( 2.757 days/year) $(p<0.05)$. R20mm (0.325 days/year) and RX1day $(0.297 \mathrm{~mm} /$ year) have revealed positive trends in the midland and highland AEZs $(p<0.05)$, respectively. In short, most of the precipitation extreme indices have shown insignificant trend across AEZs, signifying no difference was observed between 1983 and 2014.

Generally, the inconsistency of observed patterns in the precipitation extremes and uniformity in temperature extremes reveal that the local level experiences can fit into the meso-macro levels of changes in climate extremes, which in turn can confirm the robustness of extreme indices at different levels of analysis. Therefore, results from extreme event analysis could be crucial information for the design of integrated early warning systems and development of planned adaption strategies at the local level linking the meso-macro level evidence in the face of the changing extreme climate events.

\section{Data Availability}

The climate data used to support the findings of this study are available from the corresponding author upon request.

\section{Conflicts of Interest}

The authors declare that there are no conflicts of interest regarding the publication of this article.

\section{Acknowledgments}

The study was carried out with the financial support from both Wolaita Sodo University and Addis Ababa University as part of the first author's Ph.D. program. The authors appreciate the National Meteorological Agency for providing the gridded daily temperature and precipitation data.

\section{Supplementary Materials}

The supplementary material comprises three sections. Section A describes the Mann-Kendall test. Section B highlights on Sen's slope estimator test, and finally, Section C summarizes the climate extreme indices used for the trend analysis. (Supplementary Materials)

\section{References}

[1] Intergovernmental Panel on Climate Change (IPCC), Climate Change 2013: The Physical Science Basis. Contribution of Working Group I to the Fifth Assessment Report of the Intergovernmental Panel on Climate Change, T. F. Stocker, D. Qin, G.-K. Plattner et al., Eds., Cambridge University Press, Cambridge, UK, 2013.

[2] Intergovernmental Panel on Climate Change (IPCC), Climate Change 2007: Impacts, Adaptation and Vulnerability. Contribution of Working Group II to the Fourth Assessment Report of the Intergovernmental Panel on Climate Change, M. L. Parry, O. F. Canziani, J. P. Palutikof, P. J. van der Linden, and C. E. Hanson, Eds., Cambridge University Press, Cambridge, UK, 2007.

[3] Intergovernmental Panel on Climate Change (IPCC), Climate Change 2014: Synthesis Report. Contribution of Working Groups I, II and III to the Fifth Assessment Report of the Intergovernmental Panel on Climate Change, R. K. Pachauri and L. A. Meyer, Eds., IPCC, Geneva, Switzerland, 2014.

[4] P. K. Thornton, P. J. Ericksen, M. Herrero, and A. J. Challinor, "Climate variability and vulnerability to climate change: a review," Global Change Biology, vol. 20, no. 11, pp. 33133328, 2014.

[5] W. N. Adger, K. Brown, D. R. Nelson et al., "Resilience implications of policy responses to climate change," Wiley Interdisciplinary Reviews: Climate Change, vol. 2, no. 5, pp. 757-766, 2011. 
[6] Intergovernmental Panel on Climate Change (IPCC), Managing the Risks of Extreme Events and Disasters to Advance Climate Change Adaptation. A Special Report of Working Groups I and II of the Intergovernmental Panel on Climate Change, C. B. Field, V. Barros, T. F. Stocker et al., Eds., Cambridge University Press, Cambridge, UK, 2012.

[7] M. B. Sylla, N. Elguindi, F. Giorgi, and D. Wisser, "Projected robust shift of climate zones over West Africa in response to anthropogenic climate change for the late 21st century," Climatic Change, vol. 134, no. 1-2, pp. 241-253, 2016.

[8] V. Ongoma, H. Chen, and G. W. Omony, "Variability of extreme weather events over the equatorial East Africa, a case study of rainfall in Kenya and Uganda," Theoretical and Applied Climatology, vol. 131, no. 1-2, pp. 295-308, 2018.

[9] T. C. Peterson, M. P. Hoerling, P. A. Stott, and S. C. Herring, "Explaining extreme events of 2012 from a climate perspective," Bulletin of the American Meteorological Society, vol. 94, no. 9, pp. S1-S74, 2013.

[10] World Bank, Ethiopia: Economics of Adaptation to Climate Change, The World Bank Group, Washington, DC, USA, 2010.

[11] D. Conway and E. L. F. Schipper, "Adaptation to climate change in Africa: challenges and opportunities identified from Ethiopia," Global Environmental Change, vol. 21, no. 1, pp. 227-237, 2011.

[12] Ethiopian Panel of Climate Change (EPCC), First Assessment Report, Working Group II Agriculture and Food Security, Ethiopian Academy of Sciences, Addis Ababa, Ethiopia, 2015.

[13] M. A. Degefu, D. P. Rowell, and W. Bewket, "Teleconnections between Ethiopian rainfall variability and global SSTs: observations and methods for model evaluation," Meteorology and Atmospheric Physics, vol. 129, no. 2, pp. 173-186, 2017.

[14] W. Berhanu and F. Beyene, "Climate variability and household adaptation strategies in Southern Ethiopia," Sustainability, vol. 7, no. 6, pp. 6353-6375, 2015.

[15] G. J. Y. You and C. Ringler, Hydro-Economic Modeling of Climate Change Impacts in Ethiopia (No. 960), International Food Policy Research Institute (IFPRI), 2010.

[16] Food and Agricultural organization (FAO), FAO in Ethiopia El Niño Response Plan 2016, FAO, Rome, Italy, 2016, https:// reliefweb.int/report/ethiopia/fao-ethiopia-el-ni-o-response-plan2016.

[17] M. Savage, A. Mujica, F. Chiappe, and I. Ross, Climate Finance and Water Security: Bangladesh Case Study, Oxford Policy Management Limited, Oxford, UK, 2015.

[18] D. Frank, M. Reichstein, M. Bahn et al., "Effects of climate extremes on the terrestrial carbon cycle: concepts, processes and potential future impacts," Global Change Biology, vol. 21, no. 8, pp. 2861-2880, 2015.

[19] K. E. Trenberth, J. T. Fasullo, and T. G. Shepherd, "Attribution of climate extreme events," Nature Climate Change, vol. 5, no. 8, p. 725, 2015.

[20] K. E. Trenberth, "Attribution of climate variations and trends to human influences and natural variability," Wiley Interdisciplinary Reviews: Climate Change, vol. 2, no. 6, pp. 925-930, 2011.

[21] National Academies of Sciences, Engineering, and Medicine, Attribution of Extreme Weather Events in the Context of Climate Change, National Academies Press, Washington, DC, USA, 2016.

[22] L. V. Alexander, P. Hope, D. Collins, B. Trewin, A. Lynch, and N. Nicholls, "Trends in Australia's climate means and extremes: a global context," Australian Meteorological Magazine, vol. 56, no. 1, pp. 1-18, 2007.
[23] T. C. Peterson and M. J. Manton, "Monitoring changes in climate extremes: a tale of international collaboration," Bulletin of the American Meteorological Society, vol. 89, no. 9, pp. 1266-1271, 2008.

[24] J. E. Tierney, J. E. Smerdon, K. J. Anchukaitis, and R. Seager, "Multidecadal variability in East African hydroclimate controlled by the Indian Ocean," Nature, vol. 493, no. 7432, pp. 389-392, 2013.

[25] Y. Seleshi and P. Camberlin, "Recent changes in dry spell and extreme rainfall events in Ethiopia," Theoretical and Applied Climatology, vol. 83, no. 1-4, pp. 181-191, 2006.

[26] W. Bewket and D. Conway, "A note on the temporal and spatial variability of rainfall in the drought-prone Amhara region of Ethiopia," International Journal of Climatology, vol. 27, no. 11, pp. 1467-1477, 2007.

[27] G. Kebede and W. Bewket, "Variations in rainfall and extreme event indices in the wettest part of Ethiopia," SINET: Ethiopian Journal of Science, vol. 32, no. 2, pp. 129-140, 2009.

[28] H. Shang, J. Yan, M. Gebremichael, and S. M. Ayalew, "Trend analysis of extreme precipitation in the Northwestern Highlands of Ethiopia with a case study of Debre Markos," Hydrology and Earth System Sciences, vol. 15, no. 6, pp. 1937-1944, 2011.

[29] G. Kiros, A. Shetty, and L. Nandagiri, "Extreme rainfall signatures under changing climate in semi-arid northern highlands of Ethiopia," Cogent Geoscience, vol. 3, no. 1, article 1353719, 2017.

[30] M. R. Jury and C. Funk, "Climatic trends over Ethiopia: regional signals and drivers," International Journal of Climatology, vol. 33, no. 8, pp. 1924-1935, 2013.

[31] A. Mekasha, K. Tesfaye, and A. J. Duncan, "Trends in daily observed temperature and precipitation extremes over three Ethiopian eco-environments," International Journal of Climatology, vol. 34, no. 6, pp. 1990-1999, 2014.

[32] K. V. Suryabhagavan, "GIS-based climate variability and drought characterization in Ethiopia over three decades," Weather and climate extremes, vol. 15, pp. 11-23, 2017.

[33] S. Gummadi, K. P. C. Rao, J. Seid et al., "Spatio-temporal variability and trends of precipitation and extreme rainfall events in Ethiopia in 1980-2010," Theoretical and Applied Climatology, 2017.

[34] E. Viste, D. Korecha, and A. Sorteberg, "Recent drought and precipitation tendencies in Ethiopia," Theoretical and Applied Climatology, vol. 112, no. 3-4, pp. 535-551, 2013.

[35] T. T. Zeleke, F. Giorgi, G. T. Diro, and B. F. Zaitchik, "Trend and periodicity of drought over Ethiopia," International Journal of Climatology, vol. 37, no. 13, pp. 4733-4748, 2017.

[36] G. Worku, E. Teferi, A. Bantider, and Y. T. Dile, "Observed changes in extremes of daily rainfall and temperature in Jemma Sub-Basin, Upper Blue Nile Basin, Ethiopia," Theoretical and Applied Climatology, pp. 1-16, 2018.

[37] A. Kebede, B. Diekkrüger, and D. C. Edossa, "Dry spell, onset and cessation of the wet season rainfall in the Upper BaroAkobo Basin, Ethiopia," Theoretical and Applied Climatology, vol. 129, no. 3-4, pp. 849-858, 2017.

[38] M. A. Degefu and W. Bewket, "Variability and trends in rainfall amount and extreme event indices in the Omo-Ghibe River Basin, Ethiopia," Regional environmental change, vol. 14, no. 2, pp. 799-810, 2014.

[39] E. M. Fischer and R. Knutti, "Anthropogenic contribution to global occurrence of heavy-precipitation and hightemperature extremes," Nature Climate Change, vol. 5, no. 6, pp. 560-564, 2015. 
[40] S. C. Herring, M. P. Hoerling, J. P. Kossin, T. C. Peterson, and P. A. Stott, "Explaining extreme events of 2014 from a climate perspective," Bulletin of the American Meteorological Society, vol. 96, no. 12, pp. S1-S172, 2015.

[41] C. McSweeney, M. New, and G. Lizcano, UNDP Climate Change Country Profiles Ethiopia, 2008, http://countryprofiles.geog.ox.ac.uk.

[42] L. Silici, Agroecology-What it is and what it has to offer. Issue Paper 14629IIED, International Institute for Environment and Development, London, UK, 2014.

[43] H. R. Ojha, V. R. Sulaiman, P. Sultana et al., "Is South Asian agriculture adapting to climate change? Evidence from the Indo-Gangetic Plains," Agroecology and Sustainable Food Systems, vol. 38, no. 5, pp. 505-531, 2014.

[44] W. Zerihun, Vegetation Map of Ethiopia, Addis Ababa University, Addis Ababa Google Scholar, Addis Ababa, Ethiopia, 1999.

[45] Ministry of Agriculture (MoA), Agroecological Zonations of Ethiopia, Ministry of Agriculture (MoA), Addis Ababa, Ethiopia, 2000.

[46] Y. Gecho, G. Ayele, T. Lemma, and D. Alemu, "Rural household livelihood strategies: options and determinants in the case of Wolaita Zone, Southern Ethiopia," Social Sciences, vol. 3, no. 3, pp. 92-104, 2014.

[47] H. Hurni, Agroecological Belts of Ethiopia: Explanatory Notes on Three Maps at a Scale of 1: 1,000,000. Soil Conservation Research Program of Ethiopia, Addis Ababa, Ethiopia, Wittwer Druck AG, Bern, Switzerland, 1998.

[48] D. Mengistu, W. Bewket, and R. Lal, "Recent spatiotemporal temperature and rainfall variability and trends over the Upper Blue Nile River Basin, Ethiopia," International Journal of Climatology, vol. 34, no. 7, pp. 2278-2292, 2014.

[49] L. Alexander, H. Yang, and S. Perkins, ClimPACT-Indices and Software, 2013, http://www.wmo.int/pages/prog/wcp/ccl/ opace/opace4/meetings/documents/ETCRSCI_software_ documentation_v2a.doc.

[50] H. B. Mann, "Nonparametric tests against trend," Econometrica, vol. 13, no. 3, pp. 245-259, 1945.

[51] M. G. Kendall, "A new measure of rank correlation," Biometrika, vol. 30, no. 1-2, pp. 81-93, 1938.

[52] P. K. Sen, "Estimates of the regression coefficient based on Kendall's tau," Journal of the American Statistical Association, vol. 63 , no. 324 , pp. 1379-1389, 1968.

[53] E. Teferi, S. Uhlenbrook, and W. Bewket, "Inter-annual and seasonal trends of vegetation condition in the Upper Blue Nile (Abay) Basin: dual-scale time series analysis," Earth System Dynamics, vol. 6, no. 2, pp. 617-636, 2015.

[54] V. Ongoma, H. Chen, C. Gao, A. M. Nyongesa, and F. Polong, "Future changes in climate extremes over Equatorial East Africa based on CMIP5 multimodel ensemble," Natural Hazards, vol. 90, no. 2, pp. 901-920, 2018.

[55] H. Theil, "A rank-invariant method of linear and polynominal regression analysis (parts 1-3),"Proceedings of the Koninklijke Nederlandse Akademie van Wetenschappen Series A vol. 53, pp. 1397-1412, 1950.

[56] S. K. Jain and V. Kumar, "Trend analysis of rainfall and temperature data for India," Current Science, vol. 102, no. 1, pp. 37-49, 2012.

[57] G. Choi, D. Collins, G. Ren et al., "Changes in means and extreme events of temperature and precipitation in the AsiaPacific Network region, 1955-2007," International Journal of Climatology, vol. 29, no. 13, pp. 1906-1925, 2009.

[58] M. Lin, L. W. Horowitz, R. Payton, A. M. Fiore, and G. Tonnesen, "US surface ozone trends and extremes from
1980 to 2014: quantifying the roles of rising Asian emissions, domestic controls, wildfires, and climate," Atmospheric Chemistry and Physics, vol. 17, no. 4, pp. 2943-2970, 2017.

[59] V. Ongoma and H. Chen, "Temporal and spatial variability of temperature and precipitation over East Africa from 1951 to 2010," Meteorology and Atmospheric Physics, vol. 129, no. 2, pp. 131-144, 2017.

[60] M. G. Donat, L. V. Alexander, H. Yang et al., "Updated analyses of temperature and precipitation extreme indices since the beginning of the twentieth century: the HadEX2 dataset," Journal of Geophysical Research: Atmospheres, vol. 118, no. 5, pp. 2098-2118, 2013.

[61] P. A. O. Omondi, J. L. Awange, E. Forootan et al., "Changes in temperature and precipitation extremes over the Greater Horn of Africa region from 1961 to 2010," International Journal of Climatology, vol. 34, no. 4, pp. 1262-1277, 2014.

[62] X. Zhang, L. Alexander, G. C. Hegerl et al., "Indices for monitoring changes in extremes based on daily temperature and precipitation data," Wiley Interdisciplinary Reviews: Climate Change, vol. 2, no. 6, pp. 851-870, 2011.

[63] A. Adem and A. Amsalu, "Climate change in the southern lowlands of Ethiopia: Local level evidences, impacts and adaptation responses," Ethiopian Journal of Development Research, vol. 34, no. 1, pp. 1-36, 2012.

[64] T. Gebrehiwot and A. van der Veen, "Farm level adaptation to climate change: the case of farmer's in the Ethiopian Highlands," Environmental Management, vol. 52, no. 1, pp. 29-44, 2013.

[65] M. A. Zaroug, E. A. Eltahir, and F. Giorgi, "Droughts and floods over the upper catchment of the Blue Nile and their connections to the timing of El Niño and La Niña events," Hydrology and Earth System Sciences, vol. 18, no. 3, pp. 1239-1249, 2014.

[66] W. Bewket, M. Radeny, and C. Mungai, Agricultural Adaptation and Institutional Responses to Climate Change Vulnerability in Ethiopia. CCAFS Working Paper No. 106, CGIAR Research Program on Climate Change, Agriculture and Food Security (CCAFS), Copenhagen, Denmark, 2015.

[67] L. Zhou, A. Dai, Y. Dai et al., "Spatial dependence of diurnal temperature range trends on precipitation from 1950 to 2004," Climate Dynamics, vol. 32, no. 2-3, pp. 429-440, 2009.

[68] M. Hulme, R. Doherty, T. Ngara, M. New, and D. Lister, "African climate change: 1900-2100," Climate Research, vol. 17, no. 2, pp. 145-168, 2001.

[69] K. Makowski, M. Wild, and A. Ohmura, "Diurnal temperature range over Europe between 1950 and 2005," Atmospheric Chemistry and Physics, vol. 8, no. 21, pp. 6483-6498, 2008.

[70] T. M. Weldegerima, T. T. Zeleke, B. S. Birhanu, B. F. Zaitchik, and Z. A. Fetene, "Analysis of rainfall trends and its relationship with SST signals in the Lake Tana Basin, Ethiopia," Advances in Meteorology, vol. 2018, Article ID 5869010, 10 pages, 2018.

[71] A. Kidanu, K. Rovin, and K. Hardee-Cleaveland, Linking Population, Fertility and Family Planning with Adaptation to Climate Change: Views from Ethiopia, Population Action International, Washington, DC, USA, 2009.

[72] A. C. Kruger and S. S. Sekele, "Trends in extreme temperature indices in South Africa: 1962-2009," International Journal of Climatology, vol. 33, no. 3, pp. 661-676, 2013. 

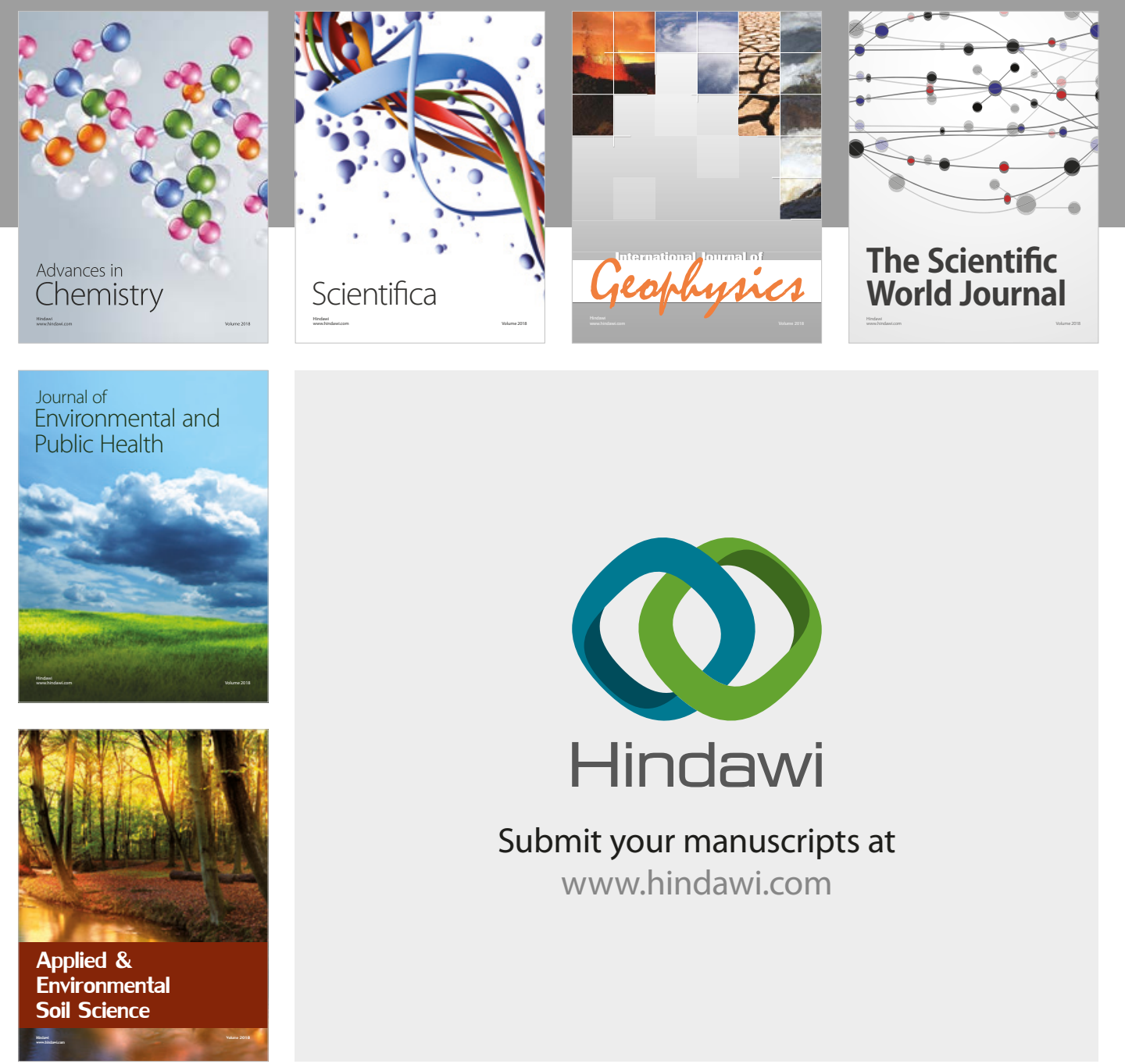

The Scientific

\section{World Journal}
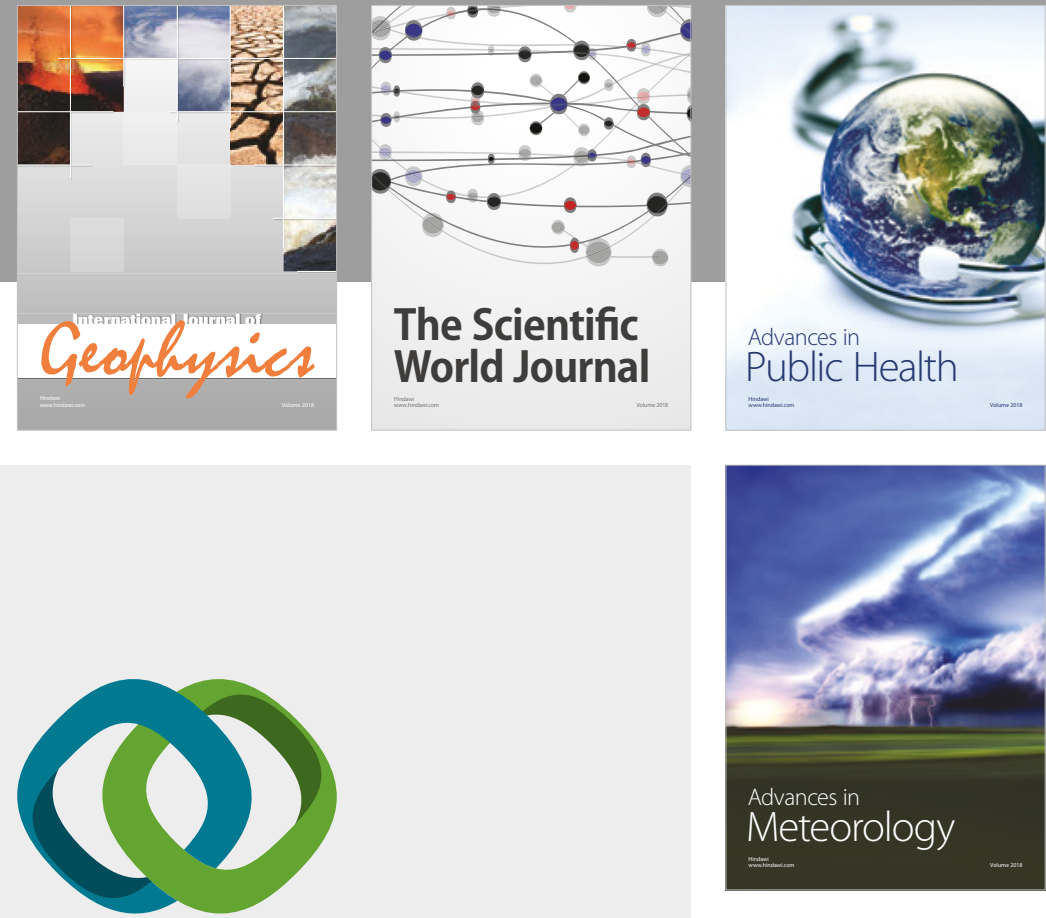

Advan

Public Health

\section{Hindawi}

Submit your manuscripts at

www.hindawi.com
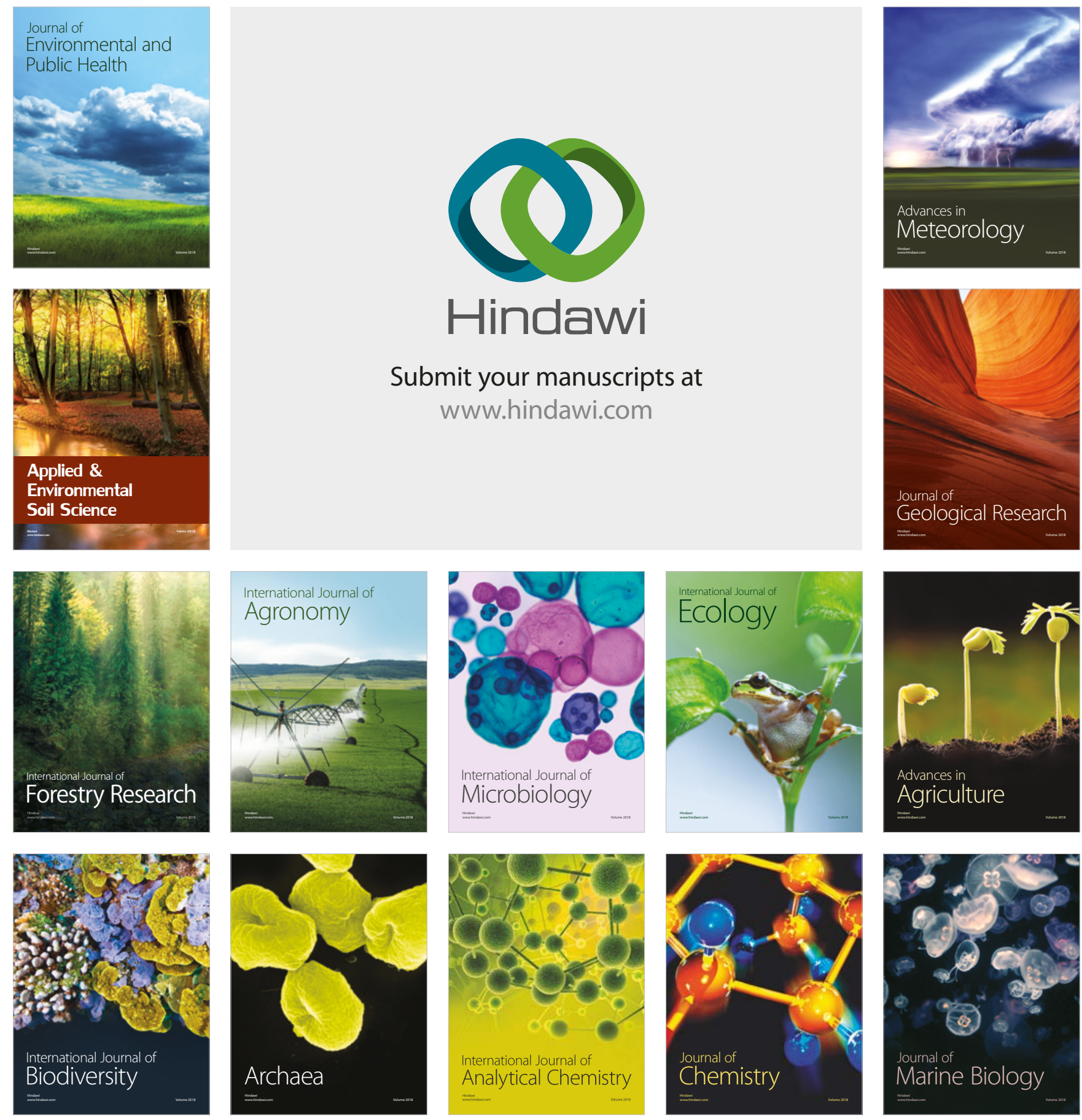